\title{
Lanostane triterpenoids from fruiting bodies of basidiomycete Stereum sp., structures and biological activities
}

\author{
Jian-Neng Yao ${ }^{1,2}$, Lin Chen ${ }^{3}$, Yang Tang ${ }^{1,2}$, He-Ping Chen ${ }^{3}$, Zhen-Zhu Zhao ${ }^{1,2}$, Zheng-Hui Li ${ }^{3}$, Tao Feng ${ }^{3}$ and \\ Ji-Kai Liu ${ }^{3}$ \\ Twelve new lanostane triterpenoids, sterenoids A-L (1-12) have been isolated from fruiting bodies of the basidiomycete Stereum \\ sp. Compounds $1-12$ are rare $14(13 \rightarrow 12)$ abeo-lanostane triterpenoids featuring remarkable $13 R$ configurations that \\ discriminate from the previously covered counterparts. Their structures and absolute configurations are assigned on the basis of \\ in-depth one- and two-dimensional NMR spectroscopic analysis, as well as unbiased quantum chemical NMR and electronic CD \\ calculations. All isolates are evaluated for their in vitro cytotoxicity against five human tumor cell lines. Compound $\mathbf{5}$ exhibits \\ potent cytotoxic activities against tumor cell lines HL-60 and SMMC-7721 with IC ${ }_{50}$ values of 4.7 and $7.6 \mu \mathrm{M}$, respectively. \\ The Journal of Antibiotics (2017) 70, 1104-1111; doi:10.1038/ja.2017.122; published online 25 October 2017
}

\section{INTRODUCTION}

Ubiquitous fungi, hailed as high-performance creators of natural occurrences, produce overwhelming second metabolites with diverse original scaffolds and versatile biological activities. ${ }^{1}$ These attractive characteristics render fungi as an integral part of mining groundbreaking drug candidates and novel small-molecule probes. ${ }^{2}$ Higher fungi, which are typically spore-bearing fruiting bodies of fungi, are a paradigm of fabricating useful natural products for the upstream of drug development. ${ }^{3}$ The genus Stereum is noted for producing a variety of biologically active second metabolites, including sesquiterpenes, ${ }^{4-8}$ dimeric sesquiterpenes, ${ }^{9-11}$ isoindolinone alkaloids, ${ }^{12,13}$ and vibralactone derivatives. ${ }^{14-18}$ Moreover, the isolates of this genus have gained organic chemists extraordinary interests. Elegant total synthesis of several isolates has been achieved. ${ }^{19-22}$ In addition, the biosynthetic pathway for vibralactone, a pancreatic lipase inhibitor from S. vibrans has been deciphered and a monooxygenase from S. vibrans is also identified. ${ }^{23,24}$

Previous chemical investigations of the genus Stereum mainly centered on culture broth, which were capable of producing diverse second metabolites by scale-up fermentation or using different culture media. Our follow-up search for bioactive natural products from higher fungi, twelve new chemical entities, sterenoids A-L (1-12, Figure 1), were isolated from fruiting bodies of Stereum sp., which is a wood decaying fungus dwelling at Xishuangbanna Tropical Botanical Garden. Compounds 1-12 are rare $14(13 \rightarrow 12)$ abeo-lanostane-type triterpenoids featuring distinctive $13 R$ configurations that are incompatible with previously covered counterparts. ${ }^{25,26}$ To the best of our knowledge, the triterpenoid, possessing this $14(13 \rightarrow 12)$ abeo- lanostane-type-6/6/5/6 ring core skeleton, was first synthesized occasionally and then was isolated from the medical plant Kadsura heteroclite. ${ }^{26,27}$ Intriguingly, triterpenoids with this tetracyclic rearranged scaffold also originated from mushrooms Tyromyces fissilis and Ganoderma lucidum..$^{28-30}$ All isolated compounds are evaluated for their cytotoxicity in vitro against five human tumor cell lines. Herein, the isolation, structure elucidation and biological evaluation of new compounds $\mathbf{1 - 1 2}$ are discussed.

\section{RESULTS AND DISCUSSION}

\section{Structure elucidation}

Compound 1, amorphous powder, had a molecular formula $\mathrm{C}_{30} \mathrm{H}_{46} \mathrm{O}_{3}$ with eight double bond equivalents as unraveled by the sodium adduct (+)-HR-ESI-MS ion at $\mathrm{m} / \mathrm{z} 477.3350[\mathrm{M}+\mathrm{Na}]^{+}$(calcd for 477.3339$)$ and the ${ }^{13} \mathrm{C}$ NMR data. The ${ }^{1} \mathrm{H}$ NMR spectrum (Table 1) of 1 revealed typical resonances for one secondary methyl at $\delta_{\mathrm{H}} 0.99\left(\mathrm{~d}, J=6.8 \mathrm{~Hz}, \mathrm{H}_{3}-21\right)$, seven tertiary methyls at $\delta_{\mathrm{H}} 1.05$ $\left(\mathrm{H}_{3}-29\right), 1.11\left(\mathrm{H}_{3}-28\right), 1.14\left(\mathrm{H}_{3}-19\right), 1.21\left(\mathrm{H}_{3}-18\right), 1.23\left(\mathrm{H}_{3}-30\right), 1.60$ $\left(\mathrm{H}_{3}-27\right)$ and $1.65\left(\mathrm{H}_{3}-26\right)$, one olefinic proton at $\delta_{\mathrm{H}} 5.12(\mathrm{t}, J=7.2 \mathrm{~Hz}$, $\mathrm{H}-24)$. A thorough analysis of the ${ }^{13} \mathrm{C}$ NMR data (Table 2), with the aid of distortionless enhancement by polarization transfer (DEPT) and HSQC spectra, unlocked 30 carbon signals, including two carbonyls $\left(\delta_{\mathrm{C}} 208.4\right.$ and $\left.\delta_{\mathrm{C}} 216.0\right), 2$ double bonds, 8 methyls, $8 s p^{3}$ methylenes, $4 s p^{3}$ methines and $4 s p^{3}$ quaternary carbons (1 oxygenated). One proton resonance at $\delta_{\mathrm{H}} 3.56$ showed no correlations with any carbons in the HSQC spectrum and thus was designated to the hydroxy group. The aforementioned functionalities carbonyls and double bonds accounted for four of the eight degrees of unsaturation and the

${ }^{1}$ State Key Laboratory of Phytochemistry and Plant Resources in West China, Kunming Institute of Botany, Chinese Academy of Sciences, Kunming, China; ${ }^{2}$ University of Chinese Academy of Sciences, Beijing, China and ${ }^{3}$ School of Pharmaceutical Sciences, South-Central University for Nationalities, Wuhan, China

Correspondence: Dr T Feng or Professor J-K Liu, School of Pharmaceutical Sciences, South-Central University for Nationalities, Wuhan 430074, China.

E-mail: tfeng@mail.scuec.edu.cn or jkliu@mail.kib.ac.cn

Received 9 July 2017; revised 13 August 2017; accepted 5 September 2017; published online 25 October 2017 


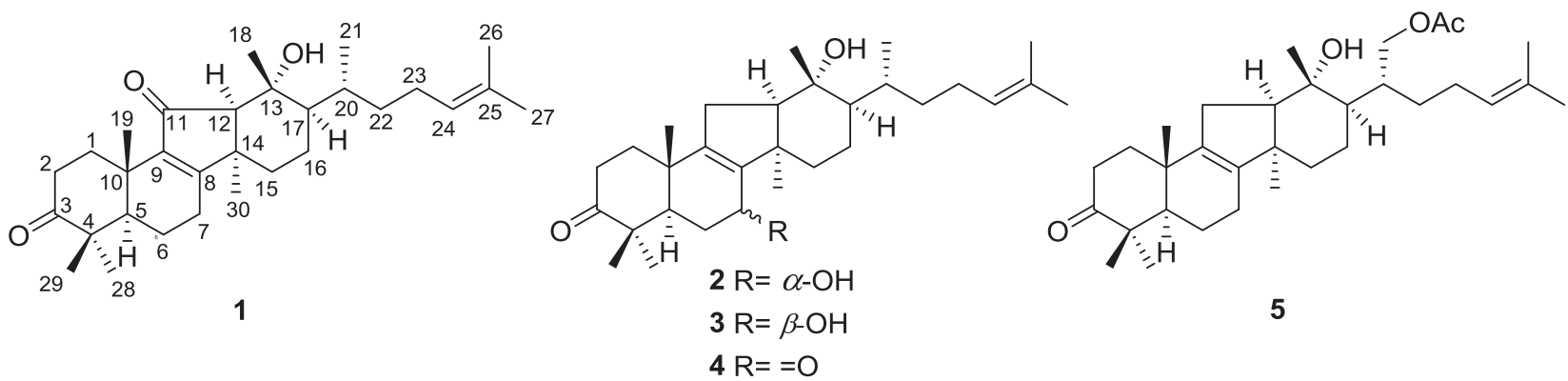

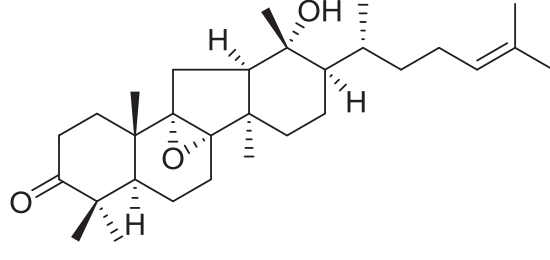

6<smiles>[R]C(O)C(C)(C)O</smiles>

Figure 1 Chemical structures of isolated compounds 1-12.

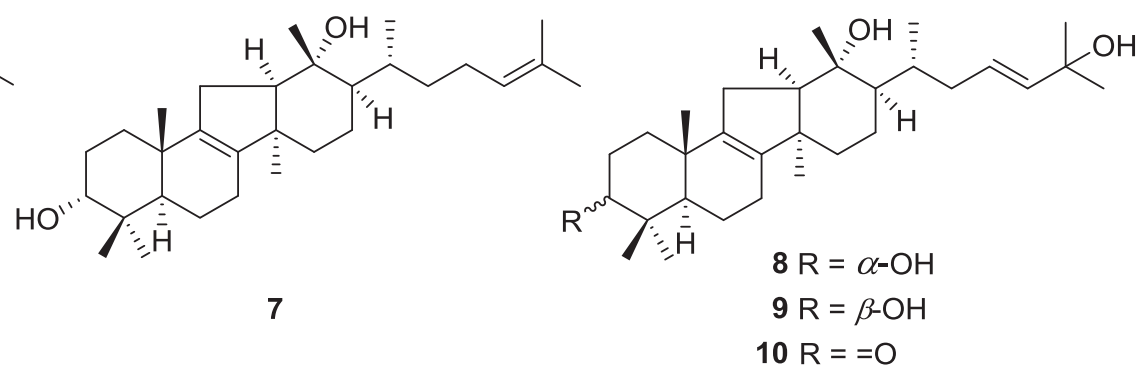

remaining four degrees of unsaturation exactly constructed four rings in the molecule.

The planar structure of $\mathbf{1}$ was established by detailed deciphering of 2D NMR spectra. ${ }^{1} \mathrm{H}-{ }^{1} \mathrm{H}$ COSY spectrum indicated eighteen protonbearing fragments as delineated in bold bonds (Figure 2). Quaternary carbons were attached to these fragments to form the scaffold of 1 by the HMBC correlations. The multiple HMBC correlations of $\mathrm{H}_{3}-28$ / C-3, C-4 and C-5; $\mathrm{H}_{3}-29 / \mathrm{C}-3, \mathrm{C}-4$ and C-5; $\mathrm{H}_{3}-19 / \mathrm{C}-1, \mathrm{C}-5, \mathrm{C}-9$ and C-10, $\mathrm{H}_{\mathrm{a}}-1 / \mathrm{C}-3$ and $\mathrm{H}-7 / \mathrm{C}-8, \mathrm{C}-9$ along with COSY correlations of $\mathrm{H}_{\mathrm{a}}-1 / \mathrm{H}_{\mathrm{a}}-2, \mathrm{H}-5 / \mathrm{H}_{\mathrm{b}}-6$ and $\mathrm{H}_{\mathrm{b}}-6 / \mathrm{H}-7$ constructed the two sixmembered carbon rings $\mathrm{A}$ and $\mathrm{B}$. The chemical shifts of 179.7 (C-8), 145.0 (C-9) and 208.4 (C-11) suggested the presence of an $\alpha, \beta$ unsaturated ketone, which was appended by one methine $(\mathrm{C}-12)$ and one quaternary carbon $(\mathrm{C}-14)$ to form the five-membered ring $\mathrm{C}$ via HMBC correlations of $\mathrm{H}_{3}-30 / \mathrm{C}-8, \mathrm{C}-14, \mathrm{C}-15$ and $\mathrm{H}-12 / \mathrm{C}-8, \mathrm{C}-11$. Furthermore, the ${ }^{1} \mathrm{H}-{ }^{1} \mathrm{H}$ COSY revealed the connection of $\mathrm{C}-15, \mathrm{C}-16$, C-17, C-20, C-22, C-23 and C-24. The key HMBC correlations of $\mathrm{H}_{3}$ $18 / \mathrm{C}-12, \mathrm{C}-13$ and $\mathrm{C}-17$ were responsible for the linkage of the sixmembered ring $\mathrm{D}$. The hydroxy group at $\delta_{\mathrm{H}} 3.56$ was fixed at $\mathrm{C}-13$ via the HMBC correlations of the hydroxy proton signal to C-12, C-13 and $\mathrm{C}-17$. Therefore, the tetracyclic triterpenoid scaffold was established. The COSY spin systems between $\mathrm{H}-17\left(\delta_{\mathrm{H}} 1.63\right)$ and $\mathrm{H}-20\left(\delta_{\mathrm{H}}\right.$ $1.81)$, as well as $\mathrm{HMBC}$ correlations of the methyl protons $\mathrm{H}_{3}-21\left(\delta_{\mathrm{H}}\right.$ $0.99)$ to $\mathrm{C}-17\left(\delta_{\mathrm{C}} 50.2\right), \mathrm{C}-20\left(\delta_{\mathrm{C}} 33.3\right)$ and $\mathrm{C}-22\left(\delta_{\mathrm{C}} 34.3\right)$ offered solid evidence that the side chain containing eight carbons was fixed to C-17. Overall, the analysis strongly hinted that $\mathbf{1}$ had a rare 14 $(13 \rightarrow 12)$ abeo-lanostane-type triterpenoid, which was similar to neokadsuranic acid A. ${ }^{26}$ The ROESY correlations of $\mathrm{H}-5$ with $\mathrm{H}_{3}-28$ and
H-12 with $\mathrm{H}-17, \mathrm{H}_{3}-30$, $\mathrm{HO}-13$, and $\mathrm{H}-17$ with $\mathrm{H}_{3}-21$ revealed that $\mathrm{H}_{3}-28, \mathrm{H}-5, \mathrm{H}-12, \mathrm{HO}-13, \mathrm{H}_{3}-30, \mathrm{H}-17$ and $\mathrm{H}_{3}-21$ were cofacial and were assigned to be $\beta$-oriented (Figure 2). The ROESY cross-peaks of $\mathrm{H}_{3}-19 / \mathrm{H}_{3}-29$ and $\mathrm{H}_{3}-18 / \mathrm{H}-20$ showed that they had $\alpha$-orientations. ${ }^{31}$ Intriguingly, the absolute configuration of $\mathrm{C}-13$ was $R$, which discriminated from the previously covered $14(13 \rightarrow 12)$ abeo-lanostane-type triterpenoids. ${ }^{25,32}$ This arbitrary assumption was confirmed by ROESY and comparison of the experimental electronic CD with quantum chemical calculated electronic $C D$ spectra as shown in Figure 3 . Hence, the absolute configuration of 1 was determined as $5 R$, $10 \mathrm{~s}, 12 R, 13 R, 14 R, 17 R, 21 R$. Taken together, the structure of $\mathbf{1}$, sterenoid A, was unambiguously characterized as 24(E)-3,11-dioxo$13 \alpha$-hydroxy-14(13 $\rightarrow$ 12)abeo-lanosta-8,24-dien.

Compound 2 and 3 were isolated as optically active, white amorphous solid, which had identical molecular formulas $\mathrm{C}_{30} \mathrm{H}_{48} \mathrm{O}_{3}$ determined by HR-ESI-MS measurements of the sodium adduct ion at $m / z \quad 479.3488 \quad[\mathrm{M}+\mathrm{Na}]^{+}$and $479.3490 \quad[\mathrm{M}+\mathrm{Na}]^{+}$(calcd for 479.3496). Analysis of the NMR data of 2 (Tables 1 and 2) suggested that it was a derivative of 1 , except for the absence of the carbonyl group for $\mathrm{C}-11$ and an additional hydroxy group at C-7. The ${ }^{1} \mathrm{H}-{ }^{1} \mathrm{H}$ COSY correlation of $\mathrm{H}-7\left(\delta_{\mathrm{H}} 4.24\right)$ with $\mathrm{H}_{\mathrm{b}}-6\left(\delta_{\mathrm{H}} 1.70\right)$ and the HMBC cross-peaks of H-7 with C-8 and C-9 supported the above deduction. The $\alpha$-oriented hydroxy group at C-7 was defined by the ROESY spectrum via the correlations between $\mathrm{H}-7 / \mathrm{H}_{3}-29$ and $\mathrm{H}_{3}-28$ / $\mathrm{H}-5$. The remaining ROESY correlations suggested that 2 shared the same configuration with that of 1 , except for the configuration of hydroxy group for C-7. In parallel, compound $\mathbf{3}$ was defined as the C-7 epimer of $\mathbf{2}$ and the configuration of hydroxy group for C-7 was 
Table $1{ }^{1} \mathrm{H}$ NMR spectroscopic data of compounds $1-6$

\begin{tabular}{|c|c|c|c|c|c|c|}
\hline No. & $1^{\mathrm{a}, \mathrm{b}}$ & $2^{\mathrm{b}, \mathrm{c}}$ & $3^{\mathrm{b}, \mathrm{c}}$ & $4^{b, c}$ & $5^{b, c}$ & $6^{a, b}$ \\
\hline 2 & $1.47 \mathrm{~m} ; 1.65 \mathrm{~m}$ & $1.88 \mathrm{~m} ; 2.55 \mathrm{~m}$ & $2.47 m ; 2.56 m$ & $2.54 m ; 2.69 m$ & $1.61 \mathrm{~m} ; 1.87 \mathrm{~m}$ & $\begin{array}{l}2.41 \text { ddd }(4.6,6.3,15.7) \\
2.56 \text { ddd }(8.7,9.5,15.7)\end{array}$ \\
\hline 5 & $1.78 \mathrm{~m}$ & $1.98 \mathrm{~m}$ & $1.57 \mathrm{~m}$ & $2.17 \mathrm{dd}(3.1,14.0)$ & $1.56 \mathrm{~m}$ & $1.96 \mathrm{~m}$ \\
\hline 6 & $1.59 \mathrm{~m} ; 1.85$ & $1.70 \mathrm{~m} ; 1.80 \mathrm{~m}$ & $1.57 \mathrm{~m} ; 2.03 \mathrm{~m}$ & $\begin{array}{c}2.30 \mathrm{dd}(3.1,16.2) \\
2.49 \mathrm{dd}(14.0,16.2)\end{array}$ & $1.51 \mathrm{~m} ; 1.69 \mathrm{~m}$ & $1.60 \mathrm{~m} ; 2.01 \mathrm{~m}$ \\
\hline 12 & $2.01 \mathrm{~s}$ & $1.75 \mathrm{~d}(6.4)$ & $1.68 \mathrm{~m}$ & $1.77 \mathrm{dd}(4.8,5.0)$ & $1.73 \mathrm{~m}$ & $1.52 \mathrm{~m}$ \\
\hline 15 & $1.59 \mathrm{~m} ; 1.72 \mathrm{~m}$ & $1.38 \mathrm{~m} ; 1.98 \mathrm{~m}$ & $1.38 \mathrm{~m} ; 2.18 \mathrm{~m}$ & $1.60 \mathrm{~m} ; 2.26 \mathrm{~m}$ & $1.27 \mathrm{~m} ; 1.78 \mathrm{~m}$ & $1.19 \mathrm{~m} ; 1.34 \mathrm{~m}$ \\
\hline 16 & $1.25 \mathrm{~m} ; 1.77 \mathrm{~m}$ & $1.04 \mathrm{~m} ; 1.62 \mathrm{~m}$ & $1.27 \mathrm{~m} ; 1.61 \mathrm{~m}$ & $1.67 \mathrm{~m} ; 2.06 \mathrm{~m}$ & $1.56 \mathrm{~m} ; 1.12 \mathrm{~m}$ & $1.35 \mathrm{~m} ; 2.05 \mathrm{~m}$ \\
\hline 17 & $1.63 \mathrm{~m}$ & $1.20 \mathrm{~m}$ & $1.21 \mathrm{~s}$ & $1.30 \mathrm{~m}$ & $1.39 \mathrm{~m}$ & $1.40 \mathrm{~m}$ \\
\hline 18 & $1.21 \mathrm{~s}$ & $0.94 \mathrm{~s}$ & $1.07 \mathrm{~s}$ & $1.02 \mathrm{~s}$ & $0.97 \mathrm{~s}$ & $1.28 \mathrm{~s}$ \\
\hline 22 & $0.99 \mathrm{~m} ; 2.50 \mathrm{~m}$ & $0.98 \mathrm{~m} ; 1.40 \mathrm{~m}$ & $1.00 \mathrm{~m} ; 1.46 \mathrm{~m}$ & $1.06 \mathrm{~m} ; 1.43 \mathrm{~m}$ & $1.16 \mathrm{~m} ; 1.38 \mathrm{~m}$ & 1.141 .62 \\
\hline 23 & $1.89 \mathrm{~m} ; 2.02 \mathrm{~m}$ & $1.87 \mathrm{~m} ; 2.05 \mathrm{~m}$ & $1.88 \mathrm{~m} ; 2.05 \mathrm{~m}$ & $1.88 \mathrm{~m} ; 2.06 \mathrm{~m}$ & $1.94 \mathrm{~m} ; 2.07 \mathrm{~m}$ & 1.932 .09 \\
\hline 24 & $5.12 \mathrm{t}(7.2)$ & $5.09 \mathrm{~s}$ & $5.09 \mathrm{t}(6.9)$ & 5.09 t (6.9) & $5.08 \mathrm{t}(7.2)$ & $5.14 \mathrm{t}(7.1)$ \\
\hline 26 & $1.65 \mathrm{~s}$ & $1.67 \mathrm{~s}$ & $1.67 \mathrm{~s}$ & $1.67 \mathrm{~s}$ & $1.67 \mathrm{~s}$ & $1.67 \mathrm{~s}$ \\
\hline 27 & $1.60 \mathrm{~s}$ & $1.59 \mathrm{~s}$ & $1.59 \mathrm{~s}$ & $1.59 \mathrm{~s}$ & $1.58 \mathrm{~s}$ & $1.18 \mathrm{~s}$ \\
\hline 28 & $1.11 \mathrm{~s}$ & $1.13 \mathrm{~s}$ & $1.09 \mathrm{~s}$ & $1.11 \mathrm{~s}$ & $1.10 \mathrm{~s}$ & $1.02 \mathrm{~s}$ \\
\hline 29 & $1.05 \mathrm{~s}$ & $1.07 \mathrm{~s}$ & $1.08 \mathrm{~s}$ & $1.12 \mathrm{~s}$ & $1.06 \mathrm{~s}$ & $1.01 \mathrm{~s}$ \\
\hline 30 & $1.23 \mathrm{~s}$ & $1.16 \mathrm{~s}$ & $1.06 \mathrm{~s}$ & $1.15 \mathrm{~s}$ & $0.95 \mathrm{~s}$ & $1.61 \mathrm{~s}$ \\
\hline$-\mathrm{OH}$ & $3.56 \mathrm{~s}$ & & & & & \\
\hline$-O A C$ & & & & & $1.58 \mathrm{~s}$ & \\
\hline
\end{tabular}

a Measured in acetone- $d_{6}$.

${ }^{b}$ Data were measured at 500,600 and $800 \mathrm{MHz}$, respectively.

cMeasured in $\mathrm{CDCl}_{3}$.

thus assigned to be $\beta$-oriented. This assignment was supported by $2 \mathrm{D}$ NMR spectra analysis, especially the ROESY correlations of H-7 with $\mathrm{H}-5$ and $\mathrm{H}_{3}-30$. Reinspection of the ${ }^{13} \mathrm{C} \mathrm{NMR}$ data of 2 and 3 uncovered that the chemical shift of C-5 $\left(\delta_{\mathrm{C}} 46.4\right)$ in 2 was major difference $\left(\Delta \delta_{\mathrm{C}} 4.7\right.$ p.p.m.) relative to that of $3\left(\delta_{\mathrm{C}} 50.2\right)$, suggesting the very existence of $\gamma$-gauche effects on the ${ }^{13} \mathrm{C}$ NMR chemical shifts. The HO-7 and H-5 of 2 were 1,3-diaxially bonded and the HO-7 was mainly responsible for steric interactions with the $\mathrm{H}-5$. On the contrary, the HO-7 of 3 was equatorial orientation and thus gave less steric hinderance. Consequently, the chemical shift of C-5 $\left(\delta_{\mathrm{C}} 46.4\right)$ in 2 was relatively upfield in comparison with that of C-5 $\left(\delta_{\mathrm{C}} 50.2\right)$ in 3. The above-discussed key differences in chemical shifts allowed a clear assignment of $\alpha$ or $\beta$ steric position of the 7 -substitutent on the basis of $\gamma$-gauche effects. ${ }^{33,34}$ The structures of 2 and 3, namely sterenoids B and $\mathrm{C}$, were thus established as $24(E)-3$-oxo-7 $\alpha, 13 \alpha$-dihydroxy-14 $(13 \rightarrow 12)$ abeo-lanosta-8,24-dien and 24(E)-3-oxo-7 $\beta, 13 \alpha$-dihydroxy$14(13 \rightarrow 12)$ abeo-lanosta-8,24-dien, respectively.

Compound 4 gave a molecular formula of $\mathrm{C}_{30} \mathrm{H}_{46} \mathrm{O}_{3}$, as established on the basis of ${ }^{13} \mathrm{C}$ NMR and HR-ESI-MS spectra, indicating compound 4 was two less hydrogen atoms than that of 2 . Their ${ }^{1} \mathrm{H}$ and ${ }^{13} \mathrm{C}$ NMR data (Tables 1 and 2 ) were similar. The major differences were that the resonances assigned to the hydroxy group in 2 replaced by a carbonyl group, together with the shift of the signals corresponding to C-7 from $\delta_{\mathrm{H}} 4.24, \delta_{\mathrm{C}} 63.4$ in 2 to $\delta_{\mathrm{C}} 196.8$ in 4 . This change was verified by the HBMC correlations of H-5 to C-7 $\left(\delta_{\mathrm{C}}\right.$ $196.8), \mathrm{H}_{\mathrm{a}}-6\left(\delta_{\mathrm{H}} 2.30\right)$ to $\mathrm{C}-7$ and $\mathrm{H}_{\mathrm{b}}-6\left(\delta_{\mathrm{C}} 2.49\right)$ to C-7. The ROESY correlation of $\mathrm{H}_{3}-18$ with $\mathrm{H}-20$ revealed that the $\mathrm{OH}-13$ was $\alpha$ - oriented. 2D NMR data analysis substantiated the one-dimensional NMR data, relative configuration and regiochemical assignments. Accordingly, the structure of 4, sterenoid D, was deduced as $24(E)$ 3,7-dioxo-13 $\alpha$-hydroxy-14(13 $\rightarrow 12)$ abeo-lanosta-8,24-dien, a congener of 2 .

Compound 5 was assigned as the molecular formula $\mathrm{C}_{32} \mathrm{H}_{50} \mathrm{O}_{4}$ by the HRESIMS ion at $m / z 521.3606[\mathrm{M}+\mathrm{Na}]^{+}$(calcd for 521.3601). Its ${ }^{1} \mathrm{H}$ and ${ }^{13} \mathrm{C}$ NMR data (Tables 1 and 2) were closely related to those of 1, with the main difference occurring for the signals of the 11substituent and 21-substituent. The 11-substituent in $\mathbf{5}$ was shifted as a methylene $\left(\delta_{\mathrm{H}} 1.31,2.30 ; \delta_{\mathrm{C}} 29.5\right)$ from the carbonyl $\left(\delta_{\mathrm{C}} 208.4\right)$ in $\mathbf{1}$ and the 21-substituent in $\mathbf{5}$ comprised the resonances of an ester carbonyl $\left(\delta_{\mathrm{C}} 171.6\right)$ and a tertiary methyl $\left(\delta_{\mathrm{H}} 1.58 ; \delta_{\mathrm{C}} 21.2\right)$. Further analysis of the HMBC spectrum confirmed an acetoxy group for the 21-substituent. Based on the ROESY spectrum and similar NMR patterns, the relative configuration of all the stereogenic centers was assigned to be identical with those of 1 . The structure of 5, sterenoid E, was thus established as 24(E)-3-oxo-13 $\alpha$-hydroxy-21-acetoxy-14 $(13 \rightarrow 12)$ abeo-lanosta-8,24-dien.

Compound 6 was obtained as a white, amorphous solid. Its molecular formula $\mathrm{C}_{30} \mathrm{H}_{48} \mathrm{O}_{3}$, with seven indices of hydrogen deficiency, was established from the HR-ESI-MS sodium adduct ion at $\mathrm{m} / \mathrm{z}$ 479.3492 $[\mathrm{M}+\mathrm{Na}]^{+}$(calcd for 479.3496). The ${ }^{1} \mathrm{H}$ and ${ }^{13} \mathrm{C} \mathrm{NMR}$ data (Tables 1 and 2) highly resembled those of $\mathbf{1}$, suggesting that these two compounds should be homologous carbocyclic skeletons and substitution patterns, except for the existence of diagnostic resonances of one $s p^{3}$ methylene $\left(\delta_{\mathrm{C}} 28.4\right)$, two oxygenated quaternary carbons C-8 $\left(\delta_{\mathrm{C}}\right.$ 
Table $2{ }^{13} \mathrm{C}$ NMR spectroscopic data of compounds $1-6$

\begin{tabular}{|c|c|c|c|c|c|c|}
\hline No. & $1^{\mathrm{a}, \mathrm{b}}$ & $2^{b, c}$ & $3^{b, c}$ & $4^{\mathrm{b}, \mathrm{c}}$ & $5^{\mathrm{b}, \mathrm{c}}$ & $6^{a, b}$ \\
\hline 1 & $34.0 \mathrm{CH}_{2}$ & $34.4 \mathrm{CH}_{2}$ & $35.1 \mathrm{CH}_{2}$ & $34.4 \mathrm{CH}_{2}$ & $34.2 \mathrm{CH}_{2}$ & $34.1 \mathrm{CH}_{2}$ \\
\hline 2 & $34.1 \mathrm{CH}_{2}$ & $34.0 \mathrm{CH}_{2}$ & $34.3 \mathrm{CH}_{2}$ & $34.1 \mathrm{CH}_{2}$ & $34.8 \mathrm{CH}_{2}$ & $34.6 \mathrm{CH}_{2}$ \\
\hline 3 & $216.0 \mathrm{C}$ & 217.6 C & $216.6 \mathrm{C}$ & $214.8 \mathrm{C}$ & $218.0 \mathrm{C}$ & $215.4 \mathrm{C}$ \\
\hline 4 & $47.5 \mathrm{C}$ & $46.4 \mathrm{C}$ & $46.8 \mathrm{C}$ & $47.0 \mathrm{C}$ & $47.0 \mathrm{C}$ & $47.4 \mathrm{C}$ \\
\hline 5 & $51.8 \mathrm{CH}$ & $45.5 \mathrm{CH}$ & $50.2 \mathrm{CH}$ & $51.4 \mathrm{CH}$ & $51.7 \mathrm{CH}$ & $45.2 \mathrm{CH}$ \\
\hline 6 & $20.0 \mathrm{CH}_{2}$ & $30.9 \mathrm{CH}_{2}$ & $31.7 \mathrm{CH}_{2}$ & $37.3 \mathrm{CH}_{2}$ & $20.1 \mathrm{CH}_{2}$ & $21.0 \mathrm{CH}_{2}$ \\
\hline 7 & $25.0 \mathrm{CH}_{2}$ & $63.4 \mathrm{CH}$ & $68.0 \mathrm{CH}$ & $196.8 \mathrm{C}$ & $22.9 \mathrm{CH}_{2}$ & $19.6 \mathrm{CH}_{2}$ \\
\hline 8 & 179.7 C & $140.7 \mathrm{C}$ & $142.0 \mathrm{C}$ & $141.3 \mathrm{C}$ & $140.9 \mathrm{C}$ & $75.3 \mathrm{C}$ \\
\hline 9 & $145.0 \mathrm{C}$ & 147.2 C & $146.1 \mathrm{C}$ & 170.7 C & $140.2 \mathrm{C}$ & $73.9 \mathrm{C}$ \\
\hline 10 & $35.5 \mathrm{C}$ & $36.3 \mathrm{C}$ & $36.3 \mathrm{C}$ & $37.5 \mathrm{C}$ & $35.7 \mathrm{C}$ & $35.9 \mathrm{C}$ \\
\hline 11 & 208.4 C & $29.5 \mathrm{CH}_{2}$ & $29.9 \mathrm{CH}_{2}$ & $31.5 \mathrm{CH}_{2}$ & $29.5 \mathrm{CH}_{2}$ & $28.4 \mathrm{CH}_{2}$ \\
\hline 12 & $67.0 \mathrm{CH}$ & $59.3 \mathrm{CH}$ & $57.6 \mathrm{CH}$ & $57.5 \mathrm{CH}$ & $58.4 \mathrm{CH}$ & $51.1 \mathrm{CH}$ \\
\hline 13 & $76.6 \mathrm{C}$ & $76.4 \mathrm{C}$ & $76.5 \mathrm{C}$ & C & $76.0 \mathrm{C}$ & $74.6 \mathrm{C}$ \\
\hline 14 & $44.2 \mathrm{C}$ & 48.4 & 49. & & & $42.1 \mathrm{C}$ \\
\hline 15 & $30.1 \mathrm{CH}_{2}$ & $32.1 \mathrm{CH}_{2}$ & $34.6 \mathrm{CH}_{2}$ & $30.8 \mathrm{CH}_{2}$ & $32.6 \mathrm{CH}_{2}$ & $28.7 \mathrm{CH}_{2}$ \\
\hline 16 & $20.9 \mathrm{CH}_{2}$ & $21.9 \mathrm{CH}_{2}$ & $22.2 \mathrm{CH}_{2}$ & $21.1 \mathrm{CH}_{2}$ & $22.4 \mathrm{CH}_{2}$ & $19.8 \mathrm{CH}_{2}$ \\
\hline 17 & $50.2 \mathrm{CH}$ & $53.5 \mathrm{CH}$ & $53.6 \mathrm{CH}$ & $52.5 \mathrm{CH}$ & 48. & $50.9 \mathrm{CH}$ \\
\hline 18 & $23.7 \mathrm{CH}_{3}$ & $19.4 \mathrm{CH}_{3}$ & $20.1 \mathrm{CH}_{3}$ & $20.3 \mathrm{CH}_{3}$ & $19.0 \mathrm{CH}_{3}$ & $29.8 \mathrm{CH}_{3}$ \\
\hline 19 & $19.5 \mathrm{CH}_{3}$ & $17.9 \mathrm{CH}_{3}$ & $19.1 \mathrm{CH}_{3}$ & $17.6 \mathrm{CH}_{3}$ & $19.2 \mathrm{CH}_{3}$ & $17.6 \mathrm{CH}_{3}$ \\
\hline 20 & $33.3 \mathrm{CH}$ & $30.7 \mathrm{CH}$ & $30.8 \mathrm{CH}$ & $31.6 \mathrm{CH}$ & $35.4 \mathrm{CH}$ & $32.3 \mathrm{CH}$ \\
\hline 21 & $20.7 \mathrm{CH}_{3}$ & $21.6 \mathrm{CH}_{3}$ & $21.7 \mathrm{CH}_{3}$ & $21.4 \mathrm{CH}_{3}$ & $68.0 \mathrm{CH}_{2}$ & $22.8 \mathrm{CH}_{3}$ \\
\hline 22 & $34.3 \mathrm{CH}_{2}$ & $33.5 \mathrm{CH}_{2}$ & $33.6 \mathrm{CH}_{2}$ & $33.4 \mathrm{CH}_{2}$ & $28.3 \mathrm{CH}_{2}$ & $35.4 \mathrm{CH}_{2}$ \\
\hline 23 & $26.9 \mathrm{CH}_{2}$ & $26.6 \mathrm{CH}_{2}$ & $26.6 \mathrm{CH}_{2}$ & $26.4 \mathrm{CH}_{2}$ & $26.6 \mathrm{CH}_{2}$ & $26.4 \mathrm{CH}_{2}$ \\
\hline 24 & $125.7 \mathrm{CH}$ & $124.7 \mathrm{CH}$ & $124.8 \mathrm{CH}$ & $124.7 \mathrm{CH}$ & $124.2 \mathrm{C}$ & $125.4 \mathrm{CH}$ \\
\hline 25 & $131.4 \mathrm{C}$ & $131.4 \mathrm{C}$ & $131.4 \mathrm{C}$ & 131.5 & $132.0 \mathrm{C}$ & $131.7 \mathrm{C}$ \\
\hline 26 & $25.8 \mathrm{CH}_{3}$ & $25.7 \mathrm{CH}_{3}$ & $25.7 \mathrm{CH}_{3}$ & $25.7 \mathrm{CH}_{3}$ & $25.7 \mathrm{CH}_{3}$ & $25.9 \mathrm{CH}_{3}$ \\
\hline 27 & $17.6 \mathrm{CH}_{3}$ & $17.6 \mathrm{CH}_{3}$ & $17.6 \mathrm{CH}_{3}$ & $17.6 \mathrm{CH}_{3}$ & $17.7 \mathrm{CH}_{3}$ & $21.0 \mathrm{CH}_{3}$ \\
\hline 28 & $27.4 \mathrm{CH}_{3}$ & $27.3 \mathrm{CH}_{3}$ & $26.7 \mathrm{CH}_{3}$ & $26.2 \mathrm{CH}_{3}$ & $27.3 \mathrm{CH}_{3}$ & $27.6 \mathrm{CH}_{3}$ \\
\hline 29 & $21.0 \mathrm{CH}_{3}$ & $20.9 \mathrm{CH}_{3}$ & $21.1 \mathrm{CH}_{3}$ & $21.2 \mathrm{CH}_{3}$ & $21.0 \mathrm{CH}_{3}$ & $21.3 \mathrm{CH}_{3}$ \\
\hline 30 & $27.5 \mathrm{CH}_{3}$ & $31.6 \mathrm{CH}_{3}$ & $29.6 \mathrm{CH}_{3}$ & $29.0 \mathrm{CH}_{3}$ & $29.0 \mathrm{CH}_{3}$ & $21.0 \mathrm{CH}_{3}$ \\
\hline \multirow[t]{2}{*}{$O A C$} & & & & & $171.6 \mathrm{C}$ & \\
\hline & & & & & $21.2 \mathrm{CH}_{3}$ & \\
\hline
\end{tabular}

Measured in acetone- $d$

bata were measured at 125,150 and $200 \mathrm{MHz}$, respectively.

cMeasured in $\mathrm{CDCl}_{3}$.

$75.3)$ and C-9 $\left(\delta_{\mathrm{C}} 73.9\right)$ replacing those of the $\alpha, \beta$-conjugated carbonyl group $\left(\delta_{\mathrm{C}} 208.4,179.7\right.$ and 145.0) of 1 (Tables 1 and 2) in the B/C-ring, respectively. This deduction was further illustrated by complete examination of 2D NMR spectra. The relative configuration of $\mathbf{6}$ was assigned via ROESY data in comparison with the counterpart of stereogenic centers in $\mathbf{1}$, with the exception of 8,9 -oxirane moiety. The ${ }^{13} \mathrm{C}$ NMR calculations with quantum-based methods pinpointed the relative configuration of epoxide ring motif in $\mathbf{6}$ as previously reviewed. ${ }^{35}$ The density functional theory (DFT) calculations of ${ }^{13} \mathrm{C}$ NMR data of the two possible stereoisomers of $\mathbf{6 a}$ and $\mathbf{6 b}$ were performed (Supplementary Figure S100; for details, see the NMR calculations for compound $\mathbf{6}$ in the Supplementary Information). The calculated NMR data of the isomer $\mathbf{6 b}$ were much closer to the experimental data of $\mathbf{6}$ as weighed by the linear correlation coefficients $\left(R^{2}\right)$ and root-mean-square deviations, suggesting that the epoxide ring motif was $\alpha$-oriented. The compound of 6, sterenoid F, was elucidated as 24(E)-3-oxo-8(9)-epoxy$13 \alpha$-hydroxy-14(13 $\rightarrow$ 12)abeo-lanosta-24-en.

Compound 7 was isolated as a white amorphous solid. It gave a molecular formula $\mathrm{C}_{30} \mathrm{H}_{50} \mathrm{O}_{2}$ based on the HR-ESI-MS ion at $\mathrm{m} / \mathrm{z}$ $465.3705[\mathrm{M}+\mathrm{Na}]^{+}$(calcd for 465.3703), corresponding to six double bond equivalents. A comprehensive analysis of ${ }^{1} \mathrm{H}$ NMR and ${ }^{13} \mathrm{C}$ NMR data (Tables 3 and 4) revealed that 7 shared a common A-D ring system with that of $\mathbf{1}$, occurred an oxygenated methine $\left(\delta_{\mathrm{C}} 76.2\right)$
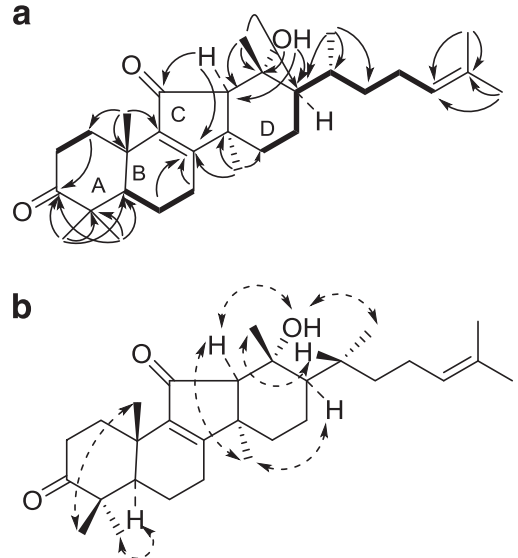

Figure $2{ }^{1} \mathrm{H}-{ }^{1} \mathrm{H}$ COSY and selected $\mathrm{HMBC}$ (a) and key ROESY (b) correlations of 1 .

and an additional $s p^{3}$ methylene $\left(\delta_{\mathrm{C}}\right.$ 29.7), and disappeared two carbonyls. One carbonyl at C-3 was shifted to a hydroxy carbon $\left(\delta_{\mathrm{C}}\right.$ 76.2) and the other at C-11 was interchanged by the $s p^{3}$ methylene, respectively. This plausible hypothesis was verified by the $\mathrm{HMBC}$ correlations from $\mathrm{H}_{3}-28 / \mathrm{H}_{3}-29$ to C-3 $\left(\delta_{\mathrm{C}} 76.2\right)$, C-4 $\left(\delta_{\mathrm{C}} 37.4\right), \mathrm{C}-5$ $\left(\delta_{\mathrm{C}} 45.9\right)$ and from $\mathrm{H}_{\mathrm{a}}-11\left(\delta_{\mathrm{H}} 2.24\right)$ to C-8 $\left(\delta_{\mathrm{C}} 139.0\right)$, C-9 $\left(\delta_{\mathrm{C}} 142.6\right)$, C-12 $\left(\delta_{\mathrm{C}} 58.1\right)$ and C-14 $\left(\delta_{\mathrm{C}} 48.7\right)$. The ROESY correlations of $\mathrm{H}_{3}-19 /$ $\mathrm{H}_{\mathrm{a}}-2, \mathrm{H}_{\mathrm{a}}-2 / \mathrm{H}-3$ and $\mathrm{H}-3 / \mathrm{H}_{3}-29$ showed that they were cofacial, indicating the hydroxy group at C-3 was $\alpha$-oriented. Taken together, compound 7, sterenoid G, was thus characterized as $24(E)-3 \alpha, 13 \alpha$ dihydroxy-14(13 $\rightarrow$ 12)abeo-lanosta-8,24-dien.

The molecular formula $\mathrm{C}_{30} \mathrm{H}_{50} \mathrm{O}_{3}$ was assigned to 8 with six indices of hydrogen deficiency by the ${ }^{13} \mathrm{C}$ NMR data and the HR-ESI-MS ion at $\mathrm{m} / z 481.3653[\mathrm{M}+\mathrm{Na}]^{+}$(calcd for 481.3625), which was more 16 mass units attributable to oxygenated motif than that of 7 . The NMR data (Tables 3 and 4) of $\mathbf{8}$ were highly consistent with those of $\mathbf{7}$, except for the side-chain moiety. The emerging chemical shifts of ${ }^{1} \mathrm{H}$ and ${ }^{13} \mathrm{C}$ NMR spectra in 8 were assignable to three methyls $\left(\delta_{\mathrm{H}} 0.95, \mathrm{~d}, J=6.9 \mathrm{~Hz} ; \delta_{\mathrm{H}} 1.30, \mathrm{~s}\right.$ and $\left.\delta_{\mathrm{H}} 1.30, \mathrm{~s}\right)$, one methylene, one methine, one persubstituted double bond $\left(\delta_{\mathrm{H}} 5.59, \mathrm{~m} ; \delta_{\mathrm{H}} 5.90\right.$, $\mathrm{d}, J=18.1 \mathrm{~Hz})$ and one oxygenated quaternary carbon $\left(\delta_{\mathrm{C}} 70.7\right)$. The ${ }^{1} \mathrm{H}_{-}{ }^{1} \mathrm{H}$ COSY correlations of $\mathrm{H}-17 / \mathrm{H}-20 / \mathrm{H}_{\mathrm{a}}-22 / \mathrm{H}-23$ and $\mathrm{HMBC}$ cross-peaks from $\mathrm{H}_{3}-21$ to $\mathrm{C}-17, \mathrm{C}-20$ and $\mathrm{C}-22$, from $\mathrm{H}_{3}-26$ and $\mathrm{H}_{3}-27$ to $\mathrm{C}-24$ and $\mathrm{C}-25$ established the side chain as depicted. The geometry of the $\Delta^{23,24}$ double bond was assigned as $E$ based on coupling constant $(18.1 \mathrm{~Hz})$. A thorough analysis of the ROESY spectrum and NMR patterns revealed that the hydroxy group at $\mathrm{C}-3$ was $\alpha$-oriented and the other stereogenic centers were assigned to be identical with those of $\mathbf{1}$. Compound $\mathbf{8}$, sterenoid $\mathrm{H}$, was thereby elucidated as $24(E)-3 \alpha, 13 \alpha, 25$-trihydroxy-14(13 $\rightarrow 12)$ abeolanosta-8,23-dien.

Analysis of HR-ESI-MS and ${ }^{13} \mathrm{C}$ NMR data indicated that compound $\mathbf{9}$ had the same molecular formula with that of $\mathbf{8}$. The ${ }^{1} \mathrm{H}$ and ${ }^{13} \mathrm{C}$ NMR data (Tables 3 and 4 ) of 9 were highly analogous to those of $\mathbf{8}$, except for minor variations at the A ring, suggesting that $\mathbf{9}$ should be the C-3 epimer of $\mathbf{8}$ and HO- 3 was determined to be $\beta$ oriented. ${ }^{25}$ This deduction was further confirmed by the ROESY correlation of $\mathrm{H}-3$ with $\mathrm{H}-5$. Therefore, compound 9, 24(E)$3 \beta, 13 \alpha, 25$-trihydroxy-14(13 $\rightarrow 12)$ abeo-lanosta-8,23-dien, was given trivial name sterenoid I.

The HR-ESI-MS ion at $m / z 479.3493 \quad[\mathrm{M}+\mathrm{Na}]^{+}$(calcd for 479.3496) and ${ }^{13} \mathrm{C}$ NMR data of compound 10 revealed the molecular 
formula $\mathrm{C}_{30} \mathrm{H}_{48} \mathrm{O}_{3}$ with seven indices of hydrogen deficiency. NMR data (Tables 3 and 4) showed that $\mathbf{1 0}$ was structurally related to $\mathbf{8}$ with the discrepancy of replacing $\mathrm{HO}-3$ via the carbonyl group. The HMBC correlations from $\mathrm{H}_{3}-28\left(\delta_{\mathrm{H}} 1.10\right)$ and $\mathrm{H}_{3}-29\left(\delta_{\mathrm{H}} 1.08\right)$ to C-3 $\left(\delta_{C}\right.$ $218.1), \mathrm{C}-4\left(\delta_{\mathrm{C}} 47.0\right)$ and $\mathrm{C}-5\left(\delta_{\mathrm{C}} 51.7\right)$ supported this hypothesis. In addition, the ROESY spectrum uncovered that all stereogenic centers were agreement with those of $\mathbf{1}$. Compound 10, sterenoid J, was thus deducted as 23(E)-3-oxo-13 $\alpha$,25-dihydroxy-14(13 $\rightarrow 12)$ abeo-lanosta8,23-dien.

Compounds 11 and 12 exhibited the identical molecular formula $\mathrm{C}_{30} \mathrm{H}_{50} \mathrm{O}_{4}$ as deduced from the HRESIMS ion at $\mathrm{m} / z 497.3603$ and $497.3600[\mathrm{M}+\mathrm{Na}]^{+}($calcd for 497.3601), respectively. Comparison of the one- and two-dimensional NMR data of 11 and 12 showed similarities, except for the subtle variations of the chemical shifts of

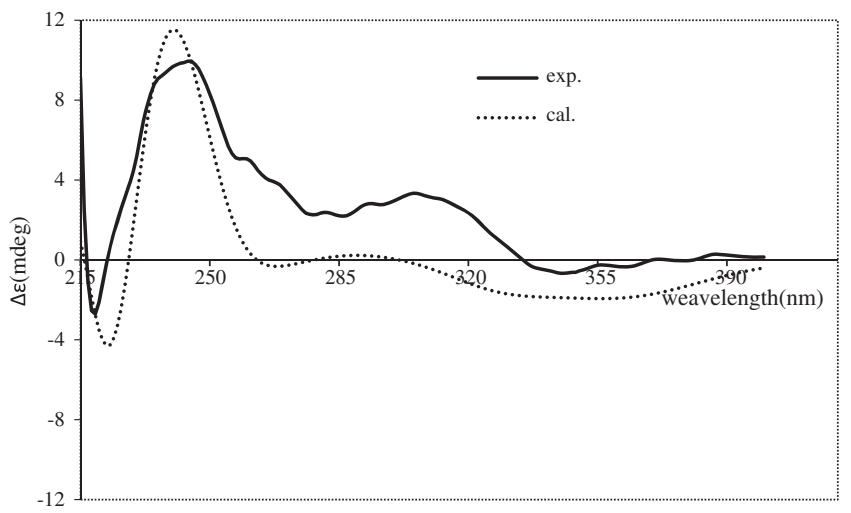

Figure 3 Experimental and calculated electronic CD (ECD) spectra of 1 (full line, experimentally recorded in methanol; dashed line, calculated for $5 R$, $10 S, 12 R, 13 R, 14 R, 17 R$ and $21 R$ configuration in methanol).
C-22 $\left(\Delta \delta_{C} 2.7\right), \mathrm{C}-23\left(\Delta \delta_{C} 0.7\right)$ and C-24 $\left(\Delta \delta_{C} 1.2\right)$ in the side-chain motif, indicating that they were a pair of C-24 epimers. The general features of the ${ }^{1} \mathrm{H}$ and ${ }^{13} \mathrm{C}$ NMR spectra of 11 closely resembled those of 1 , except that the $\Delta^{23,24}$ double bond was subject to the direct hydration. This change was supported by ${ }^{1} \mathrm{H}-{ }^{1} \mathrm{H}$ COSY correlations between $\mathrm{H}_{\mathrm{b}}-23\left(\delta_{\mathrm{H}} 1.15\right)$ and $\mathrm{H}-24\left(\delta_{\mathrm{H}} 3.28\right)$, as well as the HMBC correlations from $\mathrm{H}_{3}-26\left(\delta_{\mathrm{H}} 1.20\right)$ and $\mathrm{H}_{3}-27\left(\delta_{\mathrm{H}} 1.15\right)$ to $\mathrm{C}-24\left(\delta_{\mathrm{C}}\right.$ $79.5)$ and $\mathrm{C}-25\left(\delta_{\mathrm{C}} 73.2\right)$. Thus, the structure of 11 was thus deducted as shown (Figure 1). It was not reliable to distinguish the stereogenic centers at C-24 between $\mathbf{1 1}$ and $\mathbf{1 2}$ on the basis of available NMR data. Thus, the absolute configuration of C-24 was defined by utilizing the $\mathrm{Mo}_{2}(\mathrm{OAc})_{4}$-induced $\mathrm{CD}$ experiment for vicinal diols. ${ }^{36}$ As a result, compound 11 displayed a positive Cotton effect at $313 \mathrm{~nm}$, indicating the $24 S$ configuration for 11 . Accordingly, the $24 R$ configuration for 12 was postulated. Therefore, $\mathbf{1 1}$ and $\mathbf{1 2}$ were named sterenoids $\mathrm{K}$ and $\mathrm{L}$, and were assigned as 3-oxo-13 $\alpha, 24 S, 25$-trihydroxy-14(13 $\rightarrow 12)$ abeolanosta-8-en and 3-oxo-13 $\alpha, 24 R, 25$-trihydroxy-14(13 $\rightarrow 12)$ abeolanosta-8-en, respectively.

Biogenetically, the conversion of intact lanostane-type triterpenoids to these $14(13 \rightarrow 12)$ abeo-lanostane-type-6/6/5/6 ring core triterpenoids is likely to undergo Wagner-Meerwein rearrangement with the carbocation intermediate. The hydroxy group is subsequently embedded in the carbocation to form the $13 R$ or $13 S$ configurations. From the standpoint of physicochemical stabilization, sterenoids $\mathrm{A}-\mathrm{L}$ (1-12) with $13 R$ configurations, which mean that $\mathrm{H}-12 / \mathrm{HO}-13$ or $\mathrm{H}-17 / \mathrm{HO}-13$ are syn-coplanar, are more stable than those of $13 S$ configuration counterparts. These $13 S$ configuration counterparts embody intrinsic reactivity of E2 elimination, which requires that the leaving group and the hydrogen are anti-coplanar. Quantum chemistry calculations for natural products of structure verification are exemplified via compounds $\mathbf{1}$ and $\mathbf{6}$, suggesting that synergistic

Table $3{ }^{1} \mathrm{H}$ NMR spectroscopic data of compounds 7-12

\begin{tabular}{|c|c|c|c|c|c|c|}
\hline No. & $7^{a, b}$ & $8^{\mathrm{a}, \mathrm{b}}$ & $9^{a, b}$ & $10^{a, b}$ & $11^{\mathrm{a}, \mathrm{b}}$ & $12^{a, b}$ \\
\hline 1 & $1.41 \mathrm{~m} ; 1.55 \mathrm{~m}$ & $1.41 \mathrm{~m} ; 2.32 \mathrm{~m}$ & $1.20 \mathrm{~m} ; 1.65 \mathrm{~m}$ & $1.61 \mathrm{~m} ; 2.52 \mathrm{~m}$ & $2.50 \mathrm{~m} ; 2.54 \mathrm{~m}$ & $2.50 m ; 2.54 m$ \\
\hline 2 & $1.62 \mathrm{~m} ; 2.00 \mathrm{~m}$ & $1.63 m ; 1.99 m$ & $1.60 \mathrm{~m} ; 1.70 \mathrm{~m}$ & $1.61 \mathrm{~m} ; 1.87 \mathrm{~m}$ & $1.61 \mathrm{~m} ; 1.87 \mathrm{ddd}(4.6,7.5,13.4)$ & $1.60 \mathrm{~m} ; 1.86 \mathrm{ddd}(4.1,7.7,12.2)$ \\
\hline 3 & $3.46 \mathrm{br} \mathrm{s}$ & $3.46 \mathrm{br} \mathrm{s}$ & $3.24 \mathrm{dd}(4.5,11.3)$ & & & \\
\hline 5 & $1.46 \mathrm{~m}$ & $1.47 \mathrm{~m}$ & $0.95 \mathrm{~m}$ & $1.59 \mathrm{~m}$ & $1.56 \mathrm{~m}$ & $1.58 \mathrm{~m}$ \\
\hline 6 & $1.46 \mathrm{~m} ; 1.64 \mathrm{~m}$ & $1.47 \mathrm{~m} ; 1.64 \mathrm{~m}$ & $1.45 \mathrm{~m} ; 1.75 \mathrm{~m}$ & $1.52 \mathrm{~m} ; 1.70 \mathrm{~m}$ & $1.10 \mathrm{~m} ; 1.56 \mathrm{~m}$ & $1.51 \mathrm{~m} ; 1.69 \mathrm{~m}$ \\
\hline 7 & $1.81 \mathrm{~m} ; 1.90 \mathrm{~m}$ & $1.82 \mathrm{~m} ; 1.93 \mathrm{~m}$ & $1.76 \mathrm{~m} ; 1.93 \mathrm{~m}$ & $1.82 \mathrm{~m} ; 1.99 \mathrm{~m}$ & $1.82 \mathrm{~m} ; 1.97 \mathrm{~m}$ & $1.11 \mathrm{~m} ; 1.57 \mathrm{~m}$ \\
\hline 11 & $1.25 \mathrm{~m} ; 2.24 \mathrm{~m}$ & $1.25 \mathrm{~m} ; 2.24 \mathrm{dd}(1.8,16.9)$ & $1.25 \mathrm{~m} ; 2.24 \mathrm{~m}$ & $1.25 \mathrm{~m} ; 2.28 \mathrm{~m}$ & $2.28 \mathrm{dd}(1.8,16.3) ; 1.25 \mathrm{~m}$ & $1.25 \mathrm{~m} ; 2.28 \mathrm{dd}(1.8,16.2)$ \\
\hline 12 & $1.69 m$ & $1.70 \mathrm{~m}$ & $1.69 \mathrm{~m}$ & $1.73 \mathrm{dd}(1.8,6.5)$ & $1.71 \mathrm{dd}(1.8,6.5)$ & $1.73 \mathrm{~m}$ \\
\hline 15 & $1.24 \mathrm{~m} ; 1.69 \mathrm{~m}$ & $1.25 \mathrm{~m} ; 1.70 \mathrm{~m}$ & $1.25 \mathrm{~m} ; 1.70 \mathrm{~m}$ & $1.28 \mathrm{~m} ; 1.74 \mathrm{~m}$ & $1.27 \mathrm{~m} ; 1.76 \mathrm{~m}$ & $1.28 \mathrm{~m} ; 1.77 \mathrm{~m}$ \\
\hline 16 & $1.22 \mathrm{~m} ; 1.56 \mathrm{~m}$ & $1.26 \mathrm{~m} ; 1.59 \mathrm{~m}$ & $1.06 \mathrm{~m} ; 1.59 \mathrm{~m}$ & $1.59 \mathrm{~m} ; 2.06 \mathrm{~m}$ & $1.39 \mathrm{~m} ; 1.51 \mathrm{~m}$ & $1.59 \mathrm{~m} ; 1.79 \mathrm{~m}$ \\
\hline 17 & $1.22 \mathrm{~m}$ & $1.25 \mathrm{~m}$ & $1.25 \mathrm{~m}$ & $1.26 \mathrm{~m}$ & $1.22 \mathrm{~m}$ & $1.23 \mathrm{~m}$ \\
\hline 18 & $1.03 \mathrm{~s}$ & $1.06 \mathrm{~s}$ & $1.05 \mathrm{~s}$ & $1.04 \mathrm{~s}$ & $1.02 \mathrm{~s}$ & $1.03 \mathrm{~s}$ \\
\hline 19 & $1.03 \mathrm{~s}$ & $1.03 \mathrm{~s}$ & $1.02 \mathrm{~s}$ & $1.07 \mathrm{~s}$ & $1.06 \mathrm{~s}$ & $1.07 \mathrm{~s}$ \\
\hline 20 & $1.81 \mathrm{~s}$ & $1.88 \mathrm{~m}$ & $1.88 \mathrm{~m}$ & $1.87 \mathrm{~m}$ & $1.87 \mathrm{~m}$ & $1.82 \mathrm{~m}$ \\
\hline 21 & $1.67 \mathrm{br} \mathrm{s}$ & $0.95 \mathrm{~d}(6.9)$ & $0.95 \mathrm{~d}(5.9)$ & $0.95 \mathrm{~d}(6.8)$ & $0.96 \mathrm{~d}(6.9)$ & $0.99 \mathrm{~d}(6.8)$ \\
\hline 22 & $0.99 \mathrm{~m} ; 1.45 \mathrm{~m}$ & $1.67 \mathrm{~m} ; 2.21 \mathrm{~m}$ & $1.65 \mathrm{~m} ; 2.20 \mathrm{~m}$ & $1.66 \mathrm{~m} \mathrm{2.19m}$ & $1.69 \mathrm{~m} ; 1.50 \mathrm{~m}$ & $1.81 \mathrm{~m} ; 1.99 \mathrm{~m}$ \\
\hline 23 & $1.88 \mathrm{~m} ; 2.05 \mathrm{~m}$ & $5.59 m$ & $5.58 m$ & $5.59 \mathrm{dd}(5.9,16.0)$ & $1.25 \mathrm{~m} ; 1.39 \mathrm{~m}$ & $3.28 \mathrm{~d}(10.2)$ \\
\hline 24 & $5.10 \mathrm{t}(6.8)$ & $5.90 \mathrm{~d}(18.1)$ & $5.59 \mathrm{~d}(16.5)$ & $5.59 \mathrm{~d}(16.0)$ & $3.35 \mathrm{~d}(8.9)$ & $1.15 \mathrm{~m} ; 1.59 \mathrm{~m}$ \\
\hline 26 & $1.68 \mathrm{~s}$ & $1.30 \mathrm{~s}$ & $1.30 \mathrm{~s}$ & $1.30 \mathrm{~s}$ & $1.20 \mathrm{~s}$ & $1.21 \mathrm{~s}$ \\
\hline 27 & $1.60 \mathrm{~s}$ & $1.30 \mathrm{~s}$ & $1.30 \mathrm{~s}$ & $1.31 \mathrm{~s}$ & $1.15 \mathrm{~s}$ & $1.15 \mathrm{~s}$ \\
\hline 28 & $0.97 \mathrm{~s}$ & $0.98 \mathrm{~s}$ & $1.02 \mathrm{~s}$ & $1.10 \mathrm{~s}$ & $1.10 \mathrm{~s}$ & $1.07 \mathrm{~s}$ \\
\hline 29 & $0.89 \mathrm{~s}$ & $0.89 \mathrm{~s}$ & $0.83 \mathrm{~s}$ & $1.08 \mathrm{~s}$ & $1.07 \mathrm{~s}$ & $1.11 \mathrm{~s}$ \\
\hline 30 & $0.95 \mathrm{~s}$ & $0.96 \mathrm{~s}$ & $0.95 \mathrm{~s}$ & $0.97 \mathrm{~s}$ & $0.95 \mathrm{~s}$ & $0.96 \mathrm{~s}$ \\
\hline
\end{tabular}

${ }^{a}$ Measured in $\mathrm{CDCl}_{3}$

${ }^{b}$ Data were measured at $600 \mathrm{MHz}$. 
Table $4{ }^{13} \mathrm{C}$ NMR spectroscopic data of compounds 7-12

\begin{tabular}{|c|c|c|c|c|c|c|}
\hline No. & $7^{a, b}$ & $8^{a, b}$ & $9^{a, b}$ & $10^{a, b}$ & $11^{\mathrm{a}, \mathrm{b}}$ & $12^{\mathrm{a}, \mathrm{b}}$ \\
\hline 1 & $30.0 \mathrm{CH}_{2}$ & $30.0 \mathrm{CH}_{2}$ & $35.1 \mathrm{CH}_{2}$ & $34.3 \mathrm{CH}_{2}$ & $34.3 \mathrm{CH}_{2}$ & $34.3 \mathrm{CH}_{2}$ \\
\hline 2 & $25.6 \mathrm{CH}_{2}$ & $25.6 \mathrm{CH}_{2}$ & $27.7 \mathrm{CH}_{2}$ & $34.9 \mathrm{CH}_{2}$ & $34.9 \mathrm{CH}_{2}$ & $34.9 \mathrm{CH}_{2}$ \\
\hline 3 & $76.2 \mathrm{CH}$ & $76.2 \mathrm{CH}$ & $79.2 \mathrm{CH}$ & 218.1 C & $218.1 \mathrm{C}$ & $218.1 \mathrm{C}$ \\
\hline 4 & $37.4 \mathrm{C}$ & $37.4 \mathrm{C}$ & $38.7 \mathrm{C}$ & $47.0 \mathrm{C}$ & $47.0 \mathrm{C}$ & $47.0 \mathrm{C}$ \\
\hline 5 & $45.9 \mathrm{CH}$ & $45.9 \mathrm{CH}$ & $52.0 \mathrm{CH}$ & $51.7 \mathrm{CH}$ & $51.7 \mathrm{CH}$ & $51.7 \mathrm{CH}$ \\
\hline 6 & $18.4 \mathrm{CH}_{2}$ & $18.4 \mathrm{CH}_{2}$ & $18.6 \mathrm{CH}_{2}$ & $20.2 \mathrm{CH}_{2}$ & $20.1 \mathrm{CH}_{2}$ & $21.8 \mathrm{CH}_{2}$ \\
\hline 7 & $23.1 \mathrm{CH}_{2}$ & $23.1 \mathrm{CH}_{2}$ & $23.3 \mathrm{CH}_{2}$ & $22.8 \mathrm{CH}_{2}$ & $21.8 \mathrm{CH}_{2}$ & $22.9 \mathrm{CH}_{3}$ \\
\hline 8 & $139.0 \mathrm{C}$ & $139.0 \mathrm{C}$ & $139.3 \mathrm{C}$ & $140.3 \mathrm{C}$ & $140.3 \mathrm{C}$ & $140.4 \mathrm{C}$ \\
\hline 9 & $142.6 \mathrm{C}$ & 142.6 C & $142.3 \mathrm{C}$ & 140.6 C & 140.7 C & 140.7 C \\
\hline 10 & $35.9 \mathrm{C}$ & $35.9 \mathrm{C}$ & $36.0 \mathrm{C}$ & $35.6 \mathrm{C}$ & $35.6 \mathrm{C}$ & $35.7 \mathrm{C}$ \\
\hline 11 & $29.7 \mathrm{CH}_{2}$ & $29.7 \mathrm{CH}_{2}$ & $29.7 \mathrm{CH}_{2}$ & $29.7 \mathrm{CH}_{2}$ & $29.7 \mathrm{CH}_{2}$ & $29.6 \mathrm{CH}_{2}$ \\
\hline 12 & $58.1 \mathrm{CH}$ & $58.2 \mathrm{CH}$ & $58.1 \mathrm{CH}$ & $58.2 \mathrm{CH}$ & $58.1 \mathrm{CH}$ & $58.4 \mathrm{CH}$ \\
\hline 13 & $76.9 \mathrm{C}$ & $77.0 \mathrm{C}$ & $76.7 \mathrm{C}$ & $76.9 \mathrm{C}$ & 77. & $76.7 \mathrm{C}$ \\
\hline 14 & $48.7 \mathrm{C}$ & $48.7 \mathrm{C}$ & $48.6 \mathrm{C}$ & $48.6 \mathrm{C}$ & $48.7 \mathrm{C}$ & $48.7 \mathrm{C}$ \\
\hline 15 & $32.5 \mathrm{CH}_{2}$ & $32.4 \mathrm{CH}_{2}$ & $32.5 \mathrm{CH}_{2}$ & $32.5 \mathrm{CH}_{2}$ & $32.6 \mathrm{CH}_{2}$ & $32.7 \mathrm{CH}_{2}$ \\
\hline 16 & $21.5 \mathrm{CH}_{2}$ & $21.8 \mathrm{CH}_{2}$ & $21.8 \mathrm{CH}_{2}$ & $21.9 \mathrm{CH}_{2}$ & $30.7 \mathrm{CH}_{2}$ & $30.0 \mathrm{CH}_{2}$ \\
\hline 17 & $53.3 \mathrm{CH}$ & $52.6 \mathrm{CH}$ & $52.7 \mathrm{CH}$ & $52.8 \mathrm{CH}$ & $53.3 \mathrm{CH}$ & $53.5 \mathrm{CH}$ \\
\hline 18 & $20.2 \mathrm{CH}_{3}$ & $20.3 \mathrm{CH}_{3}$ & $20.2 \mathrm{CH}_{3}$ & $20.0 \mathrm{CH}_{3}$ & $19.8 \mathrm{CH}_{3}$ & $19.8 \mathrm{CH}_{3}$ \\
\hline 19 & $19.5 \mathrm{CH}_{3}$ & $19.6 \mathrm{CH}_{3}$ & $19.7 \mathrm{CH}_{3}$ & $20.9 \mathrm{CH}_{3}$ & $20.9 \mathrm{CH}_{3}$ & $21.0 \mathrm{CH}_{3}$ \\
\hline 20 & $31.1 \mathrm{CH}$ & $31.7 \mathrm{CH}$ & $31.7 \mathrm{CH}$ & $31.6 \mathrm{CH}$ & $31.7 \mathrm{CH}$ & $30.8 \mathrm{CH}$ \\
\hline 21 & $21.6 \mathrm{CH}_{3}$ & $21.3 \mathrm{CH}_{3}$ & $21.3 \mathrm{CH}_{3}$ & $21.3 \mathrm{CH}_{3}$ & $21.7 \mathrm{CH}_{3}$ & $21.4 \mathrm{CH}_{3}$ \\
\hline 22 & $33.5 \mathrm{CH}_{2}$ & $36.3 \mathrm{CH}_{2}$ & $36.2 \mathrm{CH}_{2}$ & $36.2 \mathrm{CH}_{2}$ & $22.9 \mathrm{CH}_{2}$ & $20.2 \mathrm{CH}_{2}$ \\
\hline 23 & $26.6 \mathrm{CH}_{2}$ & $126.6 \mathrm{CH}$ & $126.5 \mathrm{CH}$ & $126.5 \mathrm{CH}$ & $30.5 \mathrm{CH}$ & $29.8 \mathrm{CH}_{2}$ \\
\hline 24 & $124.9 \mathrm{CH}$ & $138.9 \mathrm{CH}$ & $138.9 \mathrm{CH}$ & $138.9 \mathrm{CH}$ & $79.5 \mathrm{CH}_{2}$ & $78.4 \mathrm{CH}$ \\
\hline 25 & $131.3 \mathrm{C}$ & $70.7 \mathrm{C}$ & $70.7 \mathrm{C}$ & $70.7 \mathrm{C}$ & $73.2 \mathrm{C}$ & $73.2 \mathrm{C}$ \\
\hline 26 & $25.7 \mathrm{CH}_{3}$ & $29.9 \mathrm{CH}_{3}$ & $29.9 \mathrm{CH}_{3}$ & $29.9 \mathrm{CH}_{3}$ & $26.6 \mathrm{CH}_{3}$ & $26.7 \mathrm{CH}_{3}$ \\
\hline 27 & $17.6 \mathrm{CH}_{3}$ & $29.8 \mathrm{CH}_{3}$ & $29.8 \mathrm{CH}_{3}$ & $29.8 \mathrm{CH}_{3}$ & $23.1 \mathrm{CH}_{3}$ & $23.1 \mathrm{CH}_{3}$ \\
\hline 28 & $28.2 \mathrm{CH}_{3}$ & $28.2 \mathrm{CH}_{3}$ & $28.2 \mathrm{CH}_{3}$ & $27.2 \mathrm{CH}_{3}$ & $27.2 \mathrm{CH}_{3}$ & $27.3 \mathrm{CH}_{3}$ \\
\hline 29 & $22.1 \mathrm{CH}_{3}$ & $22.1 \mathrm{CH}_{3}$ & $15.6 \mathrm{CH}_{3}$ & $19.2 \mathrm{CH}_{3}$ & $19.2 \mathrm{CH}_{3}$ & $19.2 \mathrm{CH}_{3}$ \\
\hline 30 & $28.9 \mathrm{CH}_{3}$ & $28.8 \mathrm{CH}_{3}$ & $28.9 \mathrm{CH}_{3}$ & $28.8 \mathrm{CH}_{3}$ & $28.9 \mathrm{CH}_{3}$ & $28.9 \mathrm{CH}_{3}$ \\
\hline
\end{tabular}

Measured in $\mathrm{CDCl}_{3}$

bata were measured at $150 \mathrm{MHz}$.

combination of experimental NMR data and DFT chemical shift predictions is an unbiased way for structure elucidation.

\section{Cytotoxic activities}

Compounds 1-12 were screened for cytotoxicity against five cancer cell lines HL-60 (human promyelocytic leukemia), SMMC-7721 (hepatic cancer), A-549 (lung cancer), MCF-7 (breast cancer) and SW-480 (colon cancer) using the MTS (3-(4,5-dimethylthiazol-2-yl)5-(3-carboxymethoxy-phenyl)-2-(4-sulfophenyl)-2H-tetrazolium) method, with cisplatin and paclitaxel as positive controls. These cytotoxicity results (Table 5) disclosed compound $\mathbf{5}$ displayed potent cytotoxicity against HL-60 acute leukemia and SMMC-7721 hepatic tumor cell lines with $\mathrm{IC}_{50}$ values of 4.7 and $7.6 \mu \mathrm{M}$, respectively. Although the remaining compounds (2-3 and 7-9) showed weak cytotoxicity against five tumor cell lines and compounds $(\mathbf{1}, \mathbf{6}$ and 1012) were inactive $\left(\mathrm{IC}_{50}>40 \mu \mathrm{M}\right)$. Comparison of the cytotoxic compounds 1-5, 7-9 against HL-60 tumor cell line with 6, 10-12, brief structure-activity relationship concludes that $\Delta^{8,9}$ and $\Delta^{24,25}$ double bonds are essential for cytotoxicity.

\section{EXPERIMENTAL PROCEDURES}

\section{General experimental procedures}

Optical rotations were recorded on a JASCO P-1020 digital polarimeter (Horiba, Kyoto, Japan). UV/Vis spectra were obtained using a Shimadzu UV2401PC spectrometer (Shimadzu, Kyoto, Japan). CD spectra were tested on an Applied Photophysics Chirascan Circular Dichroism Spectrometer (Applied
Photophysics Limited, Leatherhead, Surrey, UK). IR spectra were obtained using a Bruker Tensor 27 FT-IR spectrometer (Bruker Optics, Inc., Billerica, MA, USA) with $\mathrm{KBr}$ pellets. One- and two-dimensional NMR spectra were measured on a Bruker Avance III $500 \mathrm{MHz}$, Bruker Avance III $600 \mathrm{MHz}$ and Bruker Accend $800 \mathrm{MHz}$ spectrometers (Bruker Biospin GmbH, Karlsruhe, Germany). HR-ESI-MS were recorded on an Agilent 6200 Q-TOF MS system (Agilent Technologies, Santa Clara, CA, USA). Silica gel (200-300 mesh, Qingdao Haiyang Chemical Co., Ltd, Qingdao City, China) and Sephadex LH-20 (Amersham Biosciences, Upplasa City, Sweden) were used for column chromatography (CC). Medium-pressure LC was performed on a Büchi Sepacore System equipped with pump manager C-615, pump modules C-605 and fraction collector C-660 (Büchi Labortechnik AG, Fällanden, Switzerland), and columns packed with Chromatorex C-18 (40-75 mm, Fuji Silysia Chemical Ltd, Kasugai, Japan). Preparative HPLC was performed on an Agilent 1260 LC system equipped with two types of Zorbax SB-C18 columns $(9.4 \mathrm{~mm} \times 150 \mathrm{~mm}$ and $21.2 \mathrm{~mm} \times 150 \mathrm{~mm}$, particle size $5 \mathrm{~mm})$.

\section{Fungal material}

The fruiting bodies of Stereum sp. were collected in October 2013 from Xishuangbanna Tropical Botanical Garden Chinese Academy of Sciences and identified by Professor Yu-Cheng Dai (Beijing Forestry University). A voucher specimen (deposition no.: HPC 20131022) has been deposited at the Herbarium of Kunming Institute of Botany, Chinese Academy of Sciences.

\section{Extraction and isolation}

The air-dried and powdered fruiting bodies of Stereum sp. (848 g) were macerated four times with $95 \%$ ethanol to afford crude exact $(191 \mathrm{~g})$. The crude extract was suspended in water $(800 \mathrm{ml})$ and partitioned with EtOAc three times to obtain the EtOAc fraction ( $45 \mathrm{~g}$ ). The EtOAc fraction was subject to medium-pressure LC with a stepwise gradient elution of $\mathrm{MeOH} / \mathrm{H}_{2} \mathrm{O}(\mathrm{v} / \mathrm{v}$ 40:100-100:0) to afford eight fractions (A-H). Fraction F (12 g) was applied to medium-pressure LC with isocratic elution $\left(\mathrm{MeOH} / \mathrm{H}_{2} \mathrm{O}, 80: 20\right)$ to obtain seven subfactions (F1-F7) based on TLC analysis. Subfraction F2 was separated by Sephadex LH-20 (methanol) CC to give two fractions (F2a and F2b). Fraction F2a was separated repeatedly by semipreparative HPLC $\left(\mathrm{CH}_{3} \mathrm{CN} / \mathrm{H}_{2} \mathrm{O}\right.$, 40:60 to $\left.70: 30,30 \mathrm{~min}, 7 \mathrm{ml} \mathrm{min}^{-1}\right)$ to yield $8(2.5 \mathrm{mg}), 10(9 \mathrm{mg}), 11$ $(15.8 \mathrm{mg})$ and $12(3 \mathrm{mg})$. Subfraction F3 was separated by Sephadex LH-20 (methanol) CC to give four fractions (F3a-F3d) based on TLC analysis. Fraction F3a was purified by Sephadex LH-20 (acetone) CC and then was separated by semipreparative HPLC $\left(\mathrm{CH}_{3} \mathrm{CN} / \mathrm{H}_{2} \mathrm{O}, 45: 55\right.$ to $69: 31,30 \mathrm{~min}$,

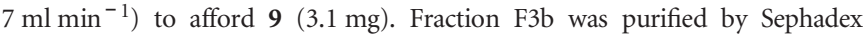
LH-20 (acetone) CC and then was separated by semipreparative HPLC

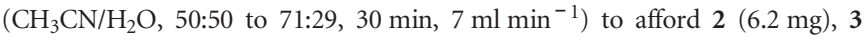
$(4 \mathrm{mg})$ and $4(2.3 \mathrm{mg})$. Subfraction F4 was separated by Sephadex LH-20 (acetone) CC to yield two fractions (F4a and F4b) based on TLC analysis. F4b was subject to a silica gel column with petroleum ether-acetone gradient solvent system (v/v, 10:1 to 2:1) to afford four fractions (F4b1-F4b4). Fraction F4b2 exhibited interesting spots in the TLC, which reacted with anisaldehyde-sulfuric acid and next was separated by preparative HPLC $\left(\mathrm{CH}_{3} \mathrm{CN} / \mathrm{H}_{2} \mathrm{O}, 62: 38\right.$ to $86: 16,30 \mathrm{~min}, 18 \mathrm{ml} \mathrm{min}^{-1}$ ), further purified by semipreparative HPLC $\left(\mathrm{CH}_{3} \mathrm{CN} / \mathrm{H}_{2} \mathrm{O}, 62: 38\right.$ to $\left.86: 14,30 \mathrm{~min}, 7 \mathrm{ml} \mathrm{min}^{-1}\right)$ to afford $1(3.6 \mathrm{mg})$ and 6 (2.1 mg). Subfraction F5 was purified by Sephadex LH-20 (acetone) CC and then was separated by semipreparative $\operatorname{HPLC}\left(\mathrm{CH}_{3} \mathrm{CN} / \mathrm{H}_{2} \mathrm{O}, 50: 50\right.$ to $71: 29$, $\left.30 \mathrm{~min}, 7 \mathrm{ml} \mathrm{min}{ }^{-1}\right)$ to afford $5(4.5 \mathrm{mg})$. Subfraction F7 was subject to column chromatography over silica gel, eluting with isocratic petroleum etheracetone (9:1) to give two fractions (F7a and F7b). Fractions F7b were purified by semipreparative HPLC $\left(\mathrm{CH}_{3} \mathrm{CN} / \mathrm{H}_{2} \mathrm{O}, 70: 30\right.$ to $\left.100: 0,30 \mathrm{~min}, 7 \mathrm{ml} \mathrm{min}{ }^{-1}\right)$ to obtain 7 (3.5 mg).

Sterenoid A (1): White solid; $[\alpha]_{\mathrm{D}}^{20}+99.8($ c $0.18, \mathrm{MeOH}) ; \mathrm{UV}(\mathrm{MeOH}) \lambda_{\max }$ $(\log \varepsilon) 202(2.89), 240(3.63) \mathrm{nm}$; electronic $\mathrm{CD}(\mathrm{MeOH}) \lambda(\Delta \varepsilon) 216(-3.8)$, $240(+11.5) 324(-0.6) \mathrm{nm}$; IR (KBr) $v_{\max } 3437,2962,2877,1696,1630,1460$, $1383,1012 \mathrm{~cm}^{-1}$; ${ }^{1} \mathrm{H}$ and ${ }^{13} \mathrm{C}$ NMR data see Tables 1 and 2; (+)-HRESIMS $\mathrm{m} / z$ 477.3350 $[\mathrm{M}+\mathrm{Na}]^{+}$(calcd for $\mathrm{C}_{30} \mathrm{H}_{46} \mathrm{O}_{3} \mathrm{Na}, 477.3339$ ).

Sterenoid B (2): White solid; $[\alpha]_{\mathrm{D}}^{20}+57.3$ ( $\left.c 0.31, \mathrm{MeOH}\right) ; \mathrm{UV}(\mathrm{MeOH}) \lambda_{\max }$ $(\log \varepsilon) 202$ (3.92), 240 (1.17) nm; IR (KBr) $v_{\max } 3445,2957,2931,2867,1702$, 
Table 5 Cytotoxicity $\mathrm{IC}_{50}$ values $(\mu \mathrm{m})$ of compounds $1-12$ against human tumor cell lines

\begin{tabular}{lccccc}
\hline \multicolumn{5}{c}{ Cell lines } \\
\cline { 2 - 6 } Compounds & $H L-60$ & A-549 & SMMC-7721 & MCF-7 & SW480 \\
\cline { 2 - 6 } $\mathbf{1}$ & 17.1 & $>40$ & $>40$ & $>40$ & $>40$ \\
$\mathbf{2}$ & 17.1 & 16.4 & 15.3 & 14.8 & 13.2 \\
$\mathbf{3}$ & 16.2 & 15.7 & 16.4 & 17.6 & 11.3 \\
$\mathbf{4}$ & 24.8 & $>40$ & $>40$ & 34.1 & $>40$ \\
$\mathbf{5}$ & 4.7 & 16.1 & 7.6 & 15.9 & 15.5 \\
$\mathbf{6}$ & $>40$ & $>40$ & $>40$ & $>40$ & $>40$ \\
$\mathbf{7}$ & 15.8 & 21.0 & 19.7 & 17.8 & 13.4 \\
$\mathbf{8}$ & 16.0 & 16.1 & 15.8 & 15.6 & 14.7 \\
$\mathbf{9}$ & 15.8 & 20.4 & 17.4 & 15.3 & 14.8 \\
10 & $>40$ & $>40$ & $>40$ & $>40$ & $>40$ \\
11 & $>40$ & $>40$ & $>40$ & 30.95 & $>40$ \\
$\mathbf{1 2}$ & $>40$ & $>40$ & $>40$ & $>40$ & $>40$ \\
Cisplatin & 3.1 & 18.0 & 13.7 & 28.4 & 14.7 \\
Paclitaxl & $<0.008$ & $<0.008$ & $<0.008$ & $<0.008$ & $<0.008$ \\
\hline
\end{tabular}

Cell lines: HL-60, acute leukemia; A-549, lung cancer; SMMC-7721, hepatic cancer; MCF-7, breast cancer; SW480, colon cancer. Cisplatin and paclitaxel were used as positive controls.

1458, 1376, 1251, 1111, $1034 \mathrm{~cm}^{-1} ;{ }^{1} \mathrm{H}$ and ${ }^{13} \mathrm{C}$ NMR data see Tables 1 and 2; (+)-HR-ESI-MS m/z $479.3488[\mathrm{M}+\mathrm{Na}]^{+}$(calcd for $\mathrm{C}_{30} \mathrm{H}_{48} \mathrm{O}_{3} \mathrm{Na}$, 479.3496).

Sterenoid C (3): White solid; $[\alpha]_{\mathrm{D}}^{20}+49.6$ ( c $\left.0.08, \mathrm{MeOH}\right)$; UV (MeOH) $\lambda_{\max }$ $(\log \varepsilon) 204$ (5.24), 253 (1.24) nm; IR (KBr) $v_{\max } 3445,2958,2930,2867,1701$, 1457, 1380, 1251, 1111, $1036 \mathrm{~cm}^{-1}$; ${ }^{1} \mathrm{H}$ and ${ }^{13} \mathrm{C}$ NMR data see Tables 1 and 2; (+)-HR-ESI-MS m/z $479.3488[\mathrm{M}+\mathrm{Na}]^{+}$(calcd for $\mathrm{C}_{30} \mathrm{H}_{48} \mathrm{O}_{3} \mathrm{Na}, 479.3496$ ).

Sterenoid D (4): White solid; $[\alpha]_{\mathrm{D}}^{20}+11.5(c 0.20, \mathrm{MeOH}) ; \mathrm{UV}(\mathrm{MeOH}) \lambda_{\max }$ $(\log \varepsilon) 202$ (2.43), 252 (2.14) nm; IR (KBr) $v_{\max } 3435,2964,2874,1707,1665$, 1458, 1381, 1247, 1113, $1034 \mathrm{~cm}^{-1}$; ${ }^{1} \mathrm{H}$ and ${ }^{13} \mathrm{C}$ NMR data see Tables 1 and 2; (+)-HR-ESI-MS $m / z 455.3527[\mathrm{M}+\mathrm{H}]^{+}\left(\right.$calcd for $\left.\mathrm{C}_{30} \mathrm{H}_{47} \mathrm{O}_{3}, 455.3520\right)$.

Sterenoid E (5): White solid; $[\alpha]_{\mathrm{D}}^{20}+44.4(c 0.27, \mathrm{MeOH})$; UV (MeOH) $\lambda_{\max }$ $(\log \varepsilon) 203$ (3.64) nm; IR (KBr) $v_{\max } 3431,3440,295,293,2868,1702,1635$, 1460, 1382, 1281, 1125, $1079 \mathrm{~cm}^{-1}$; ${ }^{1} \mathrm{H}$ and ${ }^{13} \mathrm{C}$ NMR data see Tables 1 and 2; (+)-HR-ESI-MS m/z $521.3606[\mathrm{M}+\mathrm{Na}]^{+}$(calcd for $\mathrm{C}_{32} \mathrm{H}_{50} \mathrm{O}_{4} \mathrm{Na}, 521.3601$ ).

Sterenoid F (6): White solid; $[\alpha]_{\mathrm{D}}^{20}+70.7(c 0.03, \mathrm{MeOH}) ; \mathrm{UV}(\mathrm{MeOH}) \lambda_{\max }$ (log ع) 203 (2.27) nm; IR (KBr) $v_{\max }$ 3443, 2955, 2933, 2873, 1706, 1632, 1459, $1382,1118,1084 \mathrm{~cm}^{-1} ;{ }^{1} \mathrm{H}$ and ${ }^{13} \mathrm{C}$ NMR data see Tables 1 and 2 ; (+)-HRESI-MS $m / z$ 479.3492 [M+Na] ${ }^{+}$(calcd for $\mathrm{C}_{30} \mathrm{H}_{48} \mathrm{O}_{3} \mathrm{Na}, 479.3496$ ).

Sterenoid $G$ (7): White solid; $[\alpha]_{\mathrm{D}}^{20}+14.4(c 0.26, \mathrm{MeOH})$; UV (MeOH) $\lambda_{\max }$ $(\log \varepsilon) 203(2.23) \mathrm{nm}$; IR (KBr) $v_{\max } 3430,2955,2930,2867,1707,1630,1455$, 1383, 1273, $1062 \mathrm{~cm}^{-1} ;{ }^{1} \mathrm{H}$ and ${ }^{13} \mathrm{C}$ NMR data see Tables 3 and 4; (+)-HRESI-MS m/z 465.3705 [M+Na] ${ }^{+}$(calcd for $\mathrm{C}_{30} \mathrm{H}_{50} \mathrm{O}_{2} \mathrm{Na}, 465.3703$ ).

Sterenoid $H(\boldsymbol{8})$ : White solid; $[\alpha]_{\mathrm{D}}^{20}+15.5(c 0.42, \mathrm{MeOH})$; UV (MeOH) $\lambda_{\max }$ $(\log \varepsilon) 203$ (1.93) nm; IR (KBr) $v_{\max } 3440,2957,2936,1708,1630,1457,1380$, 1158, $1062 \mathrm{~cm}^{-1}$; ${ }^{1} \mathrm{H}$ and ${ }^{13} \mathrm{C}$ NMR data see Tables 3 and 4; (+)-HR-ESI-MS $m / z 481.3653[\mathrm{M}+\mathrm{Na}]^{+}$(calcd for $\mathrm{C}_{30} \mathrm{H}_{50} \mathrm{O}_{3} \mathrm{Na}, 481.3652$ ).

Sterenoid I (9): White solid; $[\alpha]_{\mathrm{D}}^{20}+22.7(c 0.31, \mathrm{MeOH})$; UV (MeOH) $\lambda_{\max }$ $(\log \varepsilon) 203$ (2.70), $240(1.11) \mathrm{nm}$; IR (KBr) $v_{\max } 3428,2962,2932,2868,1716$, 1631, 1456, 1374, 1151, $1030 \mathrm{~cm}^{-1}$; ${ }^{1} \mathrm{H}$ and ${ }^{13} \mathrm{C}$ NMR data see Tables 3 and 4 ; (+)-HR-ESI-MS m/z $497.3403[\mathrm{M}+\mathrm{K}]^{+}$(calcd for $\left.\mathrm{C}_{30} \mathrm{H}_{50} \mathrm{O}_{3} \mathrm{~K}, 497.3403\right)$.

Sterenoid J (10): White solid; $[\alpha]_{\mathrm{D}}^{20}+6.7(c 0.41, \mathrm{MeOH})$; UV $(\mathrm{MeOH}) \lambda_{\max }$ $(\log \varepsilon) 202(3.92) \mathrm{nm}$; IR (KBr) $v_{\max }$ 3436, 2962, 2931, 2868, 1703 1631, 1459, 1380,1251,1149, $1031 \mathrm{~cm}^{-1} ;{ }^{1} \mathrm{H}$ and ${ }^{13} \mathrm{C}$ NMR data see Tables 3 and 4 ; (+)-HR-ESI-MS m/z $479.3493[\mathrm{M}+\mathrm{Na}]^{+}$(calcd for $\mathrm{C}_{30} \mathrm{H}_{48} \mathrm{O}_{3} \mathrm{Na}, 479.3496$ ).

Sterenoid K (11): White solid; $[\alpha]_{\mathrm{D}}^{20}+13.0(c 0.40, \mathrm{MeOH})$; UV $(\mathrm{MeOH}) \lambda_{\max }$ $(\log \varepsilon) 203$ (3.92), 240 (1.17) nm; IR (KBr) $v_{\max } 3440,2956,2933,2868,1701$, 1633, 1460, 1381, 1281, 1125, $1078 \mathrm{~cm}^{-1} ;{ }^{1} \mathrm{H}$ and ${ }^{13} \mathrm{C}$ NMR data see Tables 3 and $4 ;(+)-H R-E S I-M S ~ m / z ~ 497.3601[\mathrm{M}+\mathrm{Na}]^{+}$(calcd for $\mathrm{C}_{30} \mathrm{H}_{50} \mathrm{O}_{4} \mathrm{Na}$, 497.3603).
Sterenoid L (12): White solid; $[\alpha]_{\mathrm{D}}^{20}+34.7$ ( $c$ 0.45, MeOH); UV (MeOH) $\lambda_{\max }(\log \varepsilon) 203$ (1.76), 240 (1.21) nm; IR (KBr) $v_{\max } 3443,2956,2932,2866$, $1700,1632,1461,1382,1281,1124,1077 \mathrm{~cm}^{-1} ;{ }^{1} \mathrm{H}$ and ${ }^{13} \mathrm{C}$ NMR data see Tables 3 and 4; (+)-HR-ESI-MS $\mathrm{m} / \mathrm{z} \quad 497.3600 \quad[\mathrm{M}+\mathrm{Na}]^{+}$(calcd for $\mathrm{C}_{30} \mathrm{H}_{50} \mathrm{O}_{4} \mathrm{Na}$, 497.3601).

\section{Cytotoxicity assays}

The human tumor cell lines HL-60, SMMC-7721, A-549, MCF-7 and SW-480 were used in the cytotoxic assay. These cell lines were obtained from ATCC (Manassas, VA, USA). Cells were cultured in RMPI-1640 or DMEM medium (Biological Industries, Kibbutz Beit-Haemek, Israel) supplemented with $10 \%$ fetal bovine serum (Biological Industries) at $37^{\circ} \mathrm{C}$ in a humidified atmosphere with $5 \% \mathrm{CO}_{2}$. The cytotoxicity assay was evaluated by theMTS, inner salt (Promega, Madison, WI, USA) assay. ${ }^{37}$ Briefly, cells were seeded into each well of a 96-well cell culture plate. After $12 \mathrm{~h}$ of incubation at $37^{\circ} \mathrm{C}$, the test compound $(40 \mu \mathrm{M})$ was added. After incubated for $48 \mathrm{~h}$, cells were subjected to the MTS assay. Compounds with a growth inhibition rate of $50 \%$ were further evaluated at concentrations of $0.064,0.32,1.6,8$ and $40 \mu \mathrm{m}$ in triplicate, with cisplatin and paclitaxel (Sigma, St. Louis, MO, USA) as positive controls. The $\mathrm{IC}_{50}$ value of each compound was calculated with the method of Reed and Muench. ${ }^{38}$

\section{CONFLICT OF INTEREST}

The authors declare no conflict of interest.

\section{ACKNOWLEDGEMENTS}

This work was financially supported by National Natural Science Foundation of China (81561148013 and 81373289) and the Key Projects of Technological Innovation of Hubei Province (number 2016ACA138). Computational resources used in this work were supported in part by HPC Center, Kunming Institute of Botany, CAS, China. We thank Professor Yu-Cheng Dai of Beijing Forestry University, for the identification of the mushroom. We wish to thank Dr Tian Lu (Beijing Kein Research Center for Natural Sciences) for his fruitful discussions in the quantum chemical calculations with Gaussian 09.

1 Feng, T. et al. Phellibarin D with an unprecedented triterpenoid skeleton isolated from the mushroom Phellinus rhabarbarinus. Tetrahedron Lett. 57, 3544-3546 (2016).

2 Newman, D. J. \& Cragg, G. M. Natural products as sources of new drugs from 1981 to 2014. J. Nat. Prod. 79, 629-661 (2016).

3 Xiao, H. \& Zhong, J.-J. Production of useful terpenoids by higher-fungus cell factory and synthetic biology approaches. Trends Biotechnol. 34, 242-255 (2016).

$4 \mathrm{Xie}$, J., Li, L. \& Dai, Z. Isolation and identification of two new metabolites from silver leaf fungus Stereum purpureum. J. Org. Chem. 57, 2313-2316 (1992).

$5 \mathrm{Li}, \mathrm{G} . \mathrm{H}$. et al. Stereumin A-E, sesquiterpenoids from the fungus Stereum sp CCTCC AF 207024. Phytochemistry 69, 1439-1445 (2008).

6 Li, G., Liu, F., Shen, L., Zhu, H. \& Zhang, K. Stereumins H-J, stereumane-type sesquiterpenes from the fungus Stereum sp. J. Nat. Prod. 74, 296-299 (2011).

7 Isaka, M., Srisanoh, U., Sappan, M., Supothina, S. \& Boonpratuang, T. Sterostreins $\mathrm{F}-\mathrm{O}$, illudalanes and norilludalanes from cultures of the Basidiomycete Stereum ostrea BCC 22955. Phytochemistry 79, 116-120 (2012).

8 Li, J.-F., Qin, Y.-K., Tian, M.-Q., Zhang, K.-Q. \& Li, G.-H. Two new sesquiterpenes from the fungus Stereum sp NN048997. Phytochem. Lett. 10, 32-34 (2014).

9 Isaka, M., Srisanoh, U., Choowong, W. \& Boonpratuang, T. Sterostreins A-E, new terpenoids from cultures of the Basidiomycete Stereum ostrea BCC 22955. Org. Lett. 13, 4886-4889 (2011)

10 Qi, Q.-Y. et al. Sterhirsutins A and B, two new heterodimeric sesquiterpenes with a new skeleton from the culture of Stereum hirsutum collected in Tibet Plateau. Org. Lett. 16, 5092-5095 (2014).

11 Qi, Q. Y. et al. Stucturally diverse sesquiterpenes produced by a Chinese Tibet fungus Stereum hirsutum and their cytotoxic and immunosuppressant activities. Org. Lett. 17, 3098-3101 (2015)

12 Ito-Kobayashi, M. et al. Sterenin A, B, C and D, novel 11 beta-hydroxysteroid dehydrogenase type 1 inhibitors from Stereum sp SANK 21205. J. Antibiot. (Tokyo) 61 , 128-135 (2008)

13 Wang, B. T. et al. Depside alpha-glucosidase inhibitors from a culture of the mushroom Stereum hirsutum. Plant. Med. 80, 918-924 (2014).

14 Liu, D. Z. et al. Vibralactone: a lipase inhibitor with an unusual fused beta-lactone produced by cultures of the basidiomycete Boreostereum vibrans. Org. Lett. 8, 5749-5752 (2006). 
15 Jiang, M.-Y. et al. Derivatives of vibralactone from cultures of the basidiomycete Boreostereum vibrans. Chem. Pharm. Bull. (Tokyo). 56, 1286-1288 (2008).

16 Jiang, M.-Y. et al. Vibralactones D-F from cultures of the basidiomycete Boreostereum vibrans. Chem. Pharm. Bull. (Tokyo). 58, 113-116 (2010).

17 Chen, H. P. et al. Novel natural oximes and oxime esters with a vibralactone backbone from the basidiomycete Boreostereum vibrans. Chemistryopen 5, 142-149 (2016).

18 Kang, H.-S. \& Kim, J.-P. Ostalactones A-C, $\beta$ - and $\varepsilon$-lactones with lipase inhibitory activity from the cultured basidiomycete Stereum ostrea. J. Nat. Prod. 79, 3148-3151 (2016).

19 Zhou, Q. \& Snider, B. B. Synthesis of (+/-)- and (-)-vibralactone and vibralactone C. J. Org. Chem. 73, 8049-8056 (2008).

20 Yuan, C., Jiao, L. \& Yu, Z.-X. Formal total synthesis of ( \pm )-hirsutic acid C using the tandem $\mathrm{Rh}(\mathrm{I})$-catalyzed $[(5+2)+1]$ cycloaddition/aldol reaction. Tetrahedron Lett. 51, 5674-5676 (2010).

21 Lan, P., Banwell, M. G. \& Willis, A. C. Chemoenzymatic synthesis of the enantiomer of 4,12-dihydroxysterpurene, the structure assigned to a metabolite isolated from the culture broth of Stereum purpureum. Org. Lett. 17, 166-169 (2015).

22 Leeder, A. J., Heap, R. J., Brown, L. J., Franck, X. \& Brown, R. C. D. A short diastereoselective total synthesis of (+/-)-vibralactone. Org. Lett. 18, 5971-5973 (2016).

23 Zhao, P.-J., Yang, Y.-L., Du, L., Liu, J.-K. \& Zeng, Y. Elucidating the biosynthetic pathway for vibralactone: a pancreatic lipase inhibitor with a fused bicyclic betalactone. Angew. Chem. Int. Ed. 52, 2298-2302 (2013).

24 Yang, Y.-L. et al. A monooxygenase from Boreostereum vibrans catalyzes oxidative decarboxylation in a divergent vibralactone biosynthesis pathway. Angew. Chem. Int. Ed. 55, 5463-5466 (2016).

$25 \mathrm{Hu}$, Z.-X. et al. Rearranged 6/6/5/6-fused triterpenoid acids from the stems of Kadsura coccinea. J. Nat. Prod. 79, 2590-2598 (2016).

26 Kangouri, K. et al. Isolation and structure elucidation of neokadsuranic acid A, the first triterpenoid with the $14(13 \rightarrow 12)$ abeo Lanostane Skeleton, and (24Z)-3-Oxo-lanosta8,24-dien-26-oic acid. Plant. Med. 55, 297-299 (1989).
27 Edwad, O. Z. \& Paryzek, Z. Lanostane-to-cucurbitane transformation. Can. J. Chem. 61, 1973-1980 (1983).

28 Dang, N. Q., Hashimoto, T., Tanaka, M. \& Asakawa, Y. Tyromycic acids F and G: two new triterpenoids from the mushroom Tyromyces fissilis. Chem. Pharm. Bull. (Tokyo) 51, 1441-1443 (2003).

29 Quang, D. N., Hashimoto, T., Tanaka, M., Takaoka, S. \& Asakawa, Y. Tyromycic acids B - E, new lanostane triterpenoids from the mushroom Tyromyces fissilis. J. Nat. Prod. 67, 148-151 (2004).

30 Zhao, Z.-Z. et al. Two new triterpenoids from fruiting bodies of fungus Ganoderma lucidum. J. Asian Nat. Prod. Res. 17, 750-755 (2015).

$31 \mathrm{Hu}$, Z. X. et al. Kadcoccinones A-F, new biogenetically related lanostane-type triterpenoids with diverse skeletons from Kadsura coccinea. Org. Lett. 17, 4616-4619 (2015).

32 Lian-Niang, L., Hong, X., Kangouri, K., Ikeda, A. \& Omura, S. Triterpenoid acids from Kadsura longipedunculata. Neokadsuranic acids B and C: two novel triterpenoids with $14(13 \rightarrow 12)$ abeo-lanostane skeletons. Plant. Med. 55, 294-296 (1989).

33 Hammann, P., Kluge, H. \& Habermehl, G. $\gamma$-gauche Effects in the ${ }^{1} \mathrm{H}$ and ${ }^{13} \mathrm{C}$ NMR spectra of steroids. II. Magn. Reson. Chem. 29, 133-136 (1991).

34 Suzuki, S., Horii, F. \& Kurosu, H. Theoretical investigations of the gamma-gauche effect on the $\mathrm{C}-13$ chemical shifts produced by oxygen atoms at the gamma position by quantum chemistry calculations. J. Mol. Struct. 919, 290-294 (2009).

35 Zanardi, M. M., Suarez, A. G. \& Sarotti, A. M. Determination of the relative configuration of terminal and spiroepoxides by computational methods. Advantages of the inclusion of unscaled data. J. Org. Chem. 82, 1873-1879 (2017).

36 Gorecki, M. et al. Practical method for the absolute configuration assignment of tert/tert 1,2-diols using their complexes with $\mathrm{Mo}_{2}(\mathrm{OAc})_{4}$. J. Org. Chem. 72 , 2906-2916 (2007).

37 Cory, A. H., Owen, T. C., Barltrop, J. A. \& Cory, J. G. Use of an aqueous soluble tetrazolium/formazan assay for cell growth assays in culture. Cancer Commun. 3, 207-212 (1991).

38 Reed, L. J. \& Muench, H. A simple method of estimating fifty percent endpoints. Am. J. Epidemiol. 27, 493-497 (1938).

Supplementary Information accompanies the paper on The Journal of Antibiotics website (http://www.nature.com/ja) 